\title{
Molecular Modeling of Histamine Receptors-Recent Advances in Drug Discovery
}

\author{
Pakhuri Mehta, Przemysław Miszta (D) and Sławomir Filipek *(D) \\ Biological and Chemical Research Centre, Faculty of Chemistry, University of Warsaw, 02-093 Warsaw, Poland; \\ pmehta@chem.uw.edu.pl or pakhurimehta@gmail.com (P.M.); pmiszta@chem.uw.edu.pl (P.M.) \\ * Correspondence: sfilipek@chem.uw.edu.pl
}

Citation: Mehta, P.; Miszta, P.; Filipek, S. Molecular Modeling of Histamine Receptors-Recent Advances in Drug Discovery. Molecules 2021, 26, 1778. https:// doi.org/10.3390/molecules26061778

Academic Editor: Gyorgy M. Keseru

Received: 22 January 2021

Accepted: 19 March 2021

Published: 22 March 2021

Publisher's Note: MDPI stays neutral with regard to jurisdictional claims in published maps and institutional affiliations.

Copyright: (c) 2021 by the authors. Licensee MDPI, Basel, Switzerland. This article is an open access article distributed under the terms and conditions of the Creative Commons Attribution (CC BY) license (https:// creativecommons.org/licenses/by/ $4.0 /)$.

\begin{abstract}
The recent developments of fast reliable docking, virtual screening and other algorithms gave rise to discovery of many novel ligands of histamine receptors that could be used for treatment of allergic inflammatory disorders, central nervous system pathologies, pain, cancer and obesity. Furthermore, the pharmacological profiles of ligands clearly indicate that these receptors may be considered as targets not only for selective but also for multi-target drugs that could be used for treatment of complex disorders such as Alzheimer's disease. Therefore, analysis of protein-ligand recognition in the binding site of histamine receptors and also other molecular targets has become a valuable tool in drug design toolkit. This review covers the period 2014-2020 in the field of theoretical investigations of histamine receptors mostly based on molecular modeling as well as the experimental characterization of novel ligands of these receptors.
\end{abstract}

Keywords: histamine receptors; G protein-coupled receptors; computational studies; molecular docking; virtual screening; drug discovery and design

\section{Introduction}

The most recent scientific technologies have crucial applications for drug discovery and design [1-4]. In silico approaches such as virtual screening and molecular docking have been widely applied to diverse proteins including $\mathrm{G}$ protein-coupled receptors (GPCRs) which constitute the largest family of cell surface receptors in the human body comprising, among others, histamine, dopamine, adenosine or adrenergic receptors that play a key role in cellular signaling [5-8]. Developments in GPCR structural biology provide insights into GPCR-ligand binding. In the recent years, a tremendous progress has been made in the crystallization of GPCRs representing different GPCR families and subfamilies, including aminergic GPCRs such as the histamine $\mathrm{H}_{1}$ receptor $\left(\mathrm{H}_{1} \mathrm{R}\right)$. Crystallographic information concerning GPCRs is essential for understanding the possible ligand-protein interactions and diverse conformational changes associated with multiple downstream signaling paths. Obtaining crystallographic data for GPCRs has been a very difficult task due to their conformational flexibility and heterogeneity of this superfamily. The crystal structures of GPCRs proved to be very useful for structure-based ligand design methods, screening of compound libraries and building homology models of not yet crystallized GPCRs $[5,6,9,10]$. With the crystal structure of $H_{1} R$, a new opportunity has emerged to prepare the homology models of other histamine receptor subtypes $\left(H_{2} R, H_{3} R\right.$ and $\left.H_{4} R\right)$ together with a combination of ligand-based and structure-based drug design [11,12]. Structural information provided by $\mathrm{H}_{1} \mathrm{R}$ as well as adrenergic $\beta_{2}-\mathrm{AR}$ and other templates was used to resolve the structures of HRs in the inactive and active states in order to understand GPCR functionality and generate more effective drug discovery strategies. Recent investigations on the role of HRs in (patho)physiology and the use of receptor antagonists in in vivo disease models reveal a vast potential of histamine receptors in the treatment of e.g., allergic inflammation, neuropathic pain, and cancer [13-21]. The search for new and potent HR antagonists contributes to a steadily increasing number 
of potent and structurally diverse compounds [6,22-28]. Furthermore, development of ligands that are able to bind to two or more HR subtypes offers another opportunity to achieve a synergistic clinical effect mostly for allergic inflammations and neuropsychiatric disorders [29-33]. Taken together, the HRs field is showing a lot of potential to deliver another generation of potent drugs for clinical studies. In this review, we focus on the applicability of molecular modeling including drug discovery and design procedures such as molecular docking and virtual screening performed on HRs. We also review relevant clinical candidates and their therapeutic potential for the treatment of various inflammatory and allergic diseases.

\subsection{Overall Structure of the Histamine Receptors}

Histamine receptors, which belong to class A of the GPCR superfamily contain a bundle of seven antiparallel transmembrane helices, TM1 to TM7, connected by three extracellular loops, ECL1 to ECL3, and three intracellular loops, ICL1 to ICL3. Some helices contain highly conserved sequence motifs which are necessary to conduct activation steps. Furthermore, in all helices there are evolutionarily conserved residues required to preserve proper structure and function of GPCRs. Those residues are denoted by the number " 50 " in each helix in the Ballesteros-Weinstein numbering scheme: $\mathrm{N}^{1.50}, \mathrm{D}^{2.50}, \mathrm{R}^{3.50}, \mathrm{~W}^{4.50}, \mathrm{P}^{5.50}$, $\mathrm{P}^{6.50}$ and $\mathrm{P}^{7.50}$ [34-36]. In this numbering scheme each residue of GPCR is recognized by two numbers separated by a dot; the first number indicates the transmembrane helix while the second number the position of the residue relative to the most conserved residue (assigned the number 50) on the same helix in a sequential order [34]. The most recognized sequence motifs in class A GPCRs are associated with molecular switches existing also in HRs; they are: the ionic lock associated with the $\mathrm{DR}^{3.50}(\mathrm{Y} / \mathrm{F})$ motif in $\mathrm{TM} 3$, the transmission switch in TM6 associated with the $\mathrm{CWxP}^{6.50}$ motif, and the tyrosine toggle switch in TM7 ( $\mathrm{NP}^{7.50} \mathrm{xxY}$ motif) $[37,38]$. In the $\mathrm{H}_{1} \mathrm{R}$ receptor crystal structure the classical ionic lock is absent and $\mathrm{R}^{3.50}$, instead forming a salt bridge with a negatively charged residue in TM6, forms a hydrogen bond with $\mathrm{Q}^{6.36}$. The hydrogen bond can also link helices TM3 and TM6 but lack of the ionic interaction is intriguing and can modulate the activation of HRs. Since the activated structure of histamine receptors has not been determined the details of the activation steps remain unknown. Nonetheless, this structure must be similar to that of other amine-activated GPCRs, since some residues typical for this group, such as $\mathrm{D}^{3.32}$ and $\mathrm{W}^{7.40}$, are also present in all HRs [39]. $\mathrm{D}^{3.32}$ is directly bound to the ligand, while $\mathrm{W}^{7.40}$ is not in contact with the ligand but is located just behind the 3-7 lock $[37,38]$ indicating importance of this molecular switch for activation of amine-activated receptors. Apart from differences in the ligand binding sites there are also other differences in a sequence and the average sequence identity between HR subtypes is only about $20-30 \%$ [11]. HRs are divided into four subtypes, $\mathrm{H}_{1} \mathrm{R}-\mathrm{H}_{4} \mathrm{R}$, that present also some differences related to tissue expression, ligand specificity and the final cellular effects.

Since the publication of the first crystal structure of GPCR describing the 3D structure of rhodopsin in 2000, multiple GPCRs have been crystallized including one histamine receptor [40]. The structure-based drug design using HR homology modeling has only been made possible after determination of the 3D-structure of bovine rhodopsin. The crystal structure of the histamine $\mathrm{H}_{1}$ receptor was obtained in 2011 and is still the only structure of histaminergic receptor deposited in the Protein Data Bank [41]. The structure of $\mathrm{H}_{1} \mathrm{R}$ provided important insights into the ligand binding mode in HRs and was successfully applied for drug discovery and design purposes [42]. The structures of GPCRs greatly contributed to and continue to provide great opportunities for the discovery and design of novel ligands using the structure-based approaches [43-45].

\subsection{Recent Publications on Computational Studies Targeting HRs}

The research papers describing in-silico approaches applied for the discovery of novel ligand chemotypes targeting HRs published in the recent years (2014-2020) have been compiled in Figure 1. These research papers were located in PubMed, Google Scholar and 
SciFinder using the expressions "histamine receptor docking" and "histamine receptor virtual screening", and then filtering out those papers which did not directly deal with HRs. This search yielded over 80 novel research papers. Figure 1a depicts the number of research papers published yearly on each receptor as well as the number of publications covering all HRs. It can be observed that the number of research publications in the histamine $\mathrm{H}_{3} \mathrm{R}$ field shows an increasing trend after 2015 while the year 2019 saw a boom in the number of drug discovery projects in HR field with the exception of $\mathrm{H}_{2} \mathrm{R}$ and $\mathrm{H}_{4} \mathrm{R}$. In 2020 the coronavirus pandemic was probably a direct reason for a much smaller number of papers. Figure $1 \mathrm{~b}$ depicts the total number of papers published on each HR in the 2014-2020 time period. In the following sections, we review the most recent research publications describing computational approaches applied for the discovery of novel HR ligands and residues responsible for ligand binding and receptor activity.

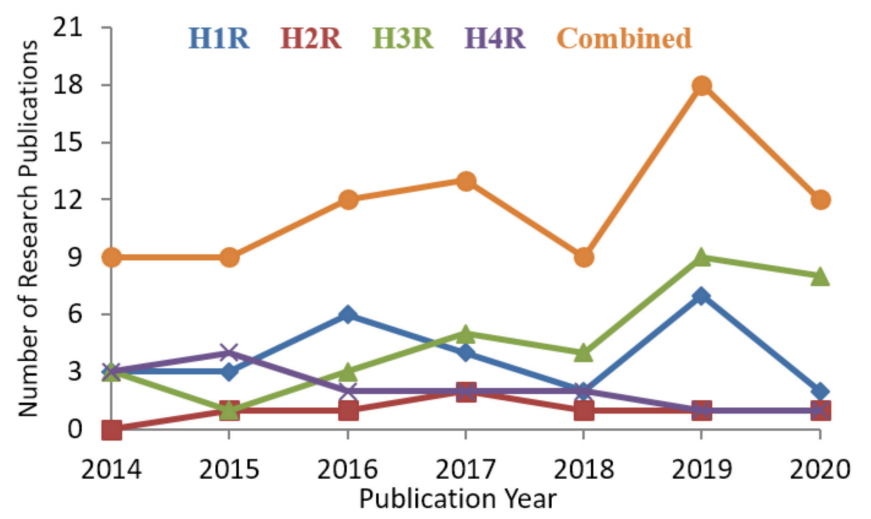

(a)

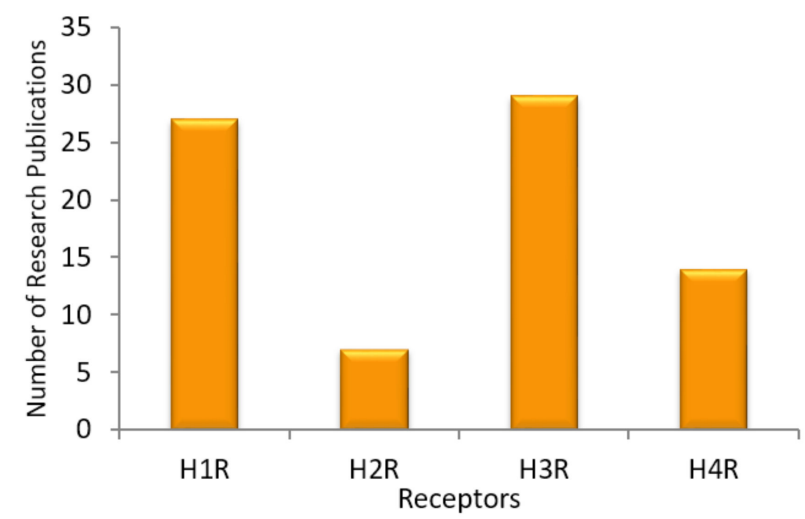

(b)

Figure 1. Number of histamine $\left(\mathrm{H}_{1}-\mathrm{H}_{4}\right)$ receptor-related computational publications in the 2014-2020 time period: (a) Yearly on each HR; (b) Total publications on each HR.

Recently, Zobayer and Hossain studied the physicochemical and structural properties of HRs. The 3D models of HRs were developed through the homology modeling methodology using the I-TASSER webserver and the best model for each receptor was selected by applying various structure-validation tools [46]. The homology models of all GPCRs were created and made available in the GPCRdb webserver which is the information hub for GPCRs and their complexes [47]. The availability of the crystal structure of $\mathrm{H}_{1} \mathrm{R}$, along with the homology models of other HRs, have resulted in the development of HRs-targeted ligands exemplified in Table 1 . The crystal structure of $\mathrm{H}_{1} \mathrm{R}$ provides the highest hit rates while the hit rates for homology models vary to some extent.

Table 1. Overview of the drug design strategies for discovery of HR ligands. In parenthesis the PDB ids of templates used in homology modeling.

\begin{tabular}{|c|c|c|c|c|c|}
\hline Receptor & Templates & Receptor State & Strategy & Hit Rate & Reference \\
\hline $\mathrm{H}_{1} \mathrm{R}$ & $\beta_{2}$-adrenergic (2R4R) & Inactive & SBVS of Phytochemical inhibitors & 5 hits & [48] \\
\hline \multirow{3}{*}{$\mathrm{H}_{1} \mathrm{R}$} & \multirow{3}{*}{ 3RZE } & \multirow{3}{*}{ Inactive } & IFP-based SBVS & $60.6 \%(20 / 33)$ & \multirow{3}{*}{ [9] } \\
\hline & & & PLANTS-based SBVS & $45.5 \%(15 / 33)$ & \\
\hline & & & $\begin{array}{c}\text { Combined IFP and PLANTS scoring } \\
\text { based SBVS }\end{array}$ & $73.1 \%(19 / 26)$ & \\
\hline $\mathrm{H}_{3} \mathrm{R}$ & $\mathrm{H}_{1} \mathrm{R}$ (3RZE) & Inactive & Pharmacophore-based virtual screening & $100 \%(5 / 5)$ & [49] \\
\hline $\mathrm{H}_{3} \mathrm{R}$ & $\mathrm{H}_{1} \mathrm{R}$ (3RZE) & Inactive & $\begin{array}{l}\text { Prospective crystal structure-based } \\
\text { pharmacophore virtual screening }\end{array}$ & $8 \%(6 / 76)$ & [50] \\
\hline $\mathrm{H}_{3} \mathrm{R}$ & $\begin{array}{c}\mathrm{M}_{3} \text { muscarinic receptor } \\
(4 \mathrm{DAJ})\end{array}$ & Inactive & $\begin{array}{c}\text { FP2 fingerprint/Electroshape / } \\
\text { Spectrophores/LBVS } \\
\text { Hybrid VS }\end{array}$ & $\begin{array}{l}50 \%(2 / 4) \\
100 \%(1 / 1)\end{array}$ & [51] \\
\hline
\end{tabular}


Table 1. Cont

\begin{tabular}{|c|c|c|c|c|c|}
\hline Receptor & Templates & Receptor State & Strategy & Hit Rate & Reference \\
\hline $\mathrm{H}_{3} \mathrm{R}$ & $\begin{array}{c}\mathrm{H}_{1} \mathrm{R}(3 \mathrm{RZE}), \mathrm{M}_{2} \\
\text { muscarinic (3UON), } \mathrm{M}_{3} \\
\text { muscarinic (4U15) }\end{array}$ & Inactive & $\begin{array}{l}\text { Pharmacophore screening and } \\
\text { redocking. }\end{array}$ & $25 \%(2 / 8)$ & [52] \\
\hline \multirow{3}{*}{$\mathrm{H}_{4} \mathrm{R}$} & \multirow{3}{*}{$\mathrm{H}_{1} \mathrm{R}$ (3RZE) } & \multirow{3}{*}{ Inactive } & Single Structure & $22 \%(11 / 50)$ & \multirow{3}{*}{ [6] } \\
\hline & & & Ensemble Docking & $16 \%(8 / 50)$ & \\
\hline & & & Overlap hits & $27 \%(4 / 15)$ & \\
\hline $\mathrm{H}_{4} \mathrm{R}$ & $\mathrm{H}_{1} \mathrm{R}$ (3RZE) & Inactive & $\begin{array}{l}\text { Ligand-based chemoinformatics: } \\
\text { Intelligent Learning Engine/Iterative } \\
\text { Stochastic Elimination/Extended } \\
\text { connectivity fingerprint (ECFP4). }\end{array}$ & 11 hits & [12] \\
\hline \multirow[b]{2}{*}{$\mathrm{H}_{4} \mathrm{R}$} & \multirow[b]{2}{*}{ Bovine rhodopsin (1F88) } & \multirow[b]{2}{*}{ Inactive } & Ensemble docking & $5.3 \%(4 / 75)$ & \multirow[b]{2}{*}{ [25] } \\
\hline & & & $\begin{array}{l}\text { Ensemble docking followed by } \\
\text { consensus scoring. }\end{array}$ & $15.4 \%(2 / 13)$ & \\
\hline \multirow{2}{*}{$\mathrm{H}_{4} \mathrm{R}$} & $\beta_{2} \mathrm{R}(2 \mathrm{RH} 1)$ & Inactive & Prospective SBVS. & $26 \%(6 / 23)$ & \multirow{2}{*}{ [53] } \\
\hline & $\mathrm{H}_{1} \mathrm{R}$ (3RZE) & Inactive & Prospective SBVS. & $21.4 \%(3 / 14)$ & \\
\hline $\mathrm{H}_{4} \mathrm{R}$ & Bovine rhodopsin $(1 \mathrm{~L} 9 \mathrm{H})$ & Inactive & $\begin{array}{l}\text { Homology model refined by "scout } \\
\text { screening", VS using ECFP_4 } \\
\text { fingerprint. }\end{array}$ & $23 \%(28 / 120)$ & {$[22,23]$} \\
\hline $\mathrm{H}_{4} \mathrm{R}$ & $\mathrm{H}_{1} \mathrm{R}$ (3RZE) & Inactive & $\begin{array}{l}\text { Pharmacophore-based virtual screening } \\
\text { (Tanimoto similarity coefficient } \geq 0.9 \text { ). }\end{array}$ & $1 \%(3 / 291)$ & [26] \\
\hline
\end{tabular}

\section{HR-Targeted Ligands and Receptor Binding Site of Inactive/Active States of HRs}

Virtual screenings and molecular docking have led the path towards development of novel HR-targeted ligands with high affinities for particular subtypes of HRs (Figure 2). The novel ligands display predicted interactions with crucial residues in the binding sites of HRs. In Table 2 these residues are presented with their original numbers from particular receptors and also in B-W numbering scheme.

\subsection{Computational Studies on Histamine $H_{1}$ Receptor and Its ligands}

\subsubsection{Structural Aspects of Histamine $\mathrm{H}_{1}$ Receptor}

The first HR deposited in Protein Data Bank in 2011 was $\mathrm{H}_{1} \mathrm{R}$ in an inactive conformational state (PDB id:3RZE) [41]. The orthosteric binding site of this receptor is confined between the upper regions of the transmembrane helices (TMHs) and the extracellular loops (ECLs). $\mathrm{H}_{1} \mathrm{R}$ (UniProt id:P35367, 487 amino acids) crystal structure has a disulphide bond linking C180 (ECL2) with the extracellular end of TM3 $\left(\mathrm{C}^{3.25}\right)$ but it is lacking the palmitoylation site at the end of helix $\mathrm{H} 8$ which is present in many other GPCRs. The antagonist orthosteric binding site in the $\mathrm{H}_{1} \mathrm{R}$ structure is divided into three regions lined by crucial residues as suggested by several site-directed mutagenesis studies: (i) the aminebinding region $\left(\mathrm{D}^{3.32}, \mathrm{~W}^{6.48}, \mathrm{Y}^{6.51}, \mathrm{I}^{7.39}\right.$, and $\left.\mathrm{Y}^{7.43}\right)$; (ii) the upper aromatic region $\left(\mathrm{Y}^{3.33}\right.$, $\mathrm{W}^{4.56}, \mathrm{Y}^{6.51}, \mathrm{~F}^{6.52}$, and $\mathrm{F}^{6.55}$ ), and (iii) the lower aromatic region $\left(\mathrm{F}^{5.47}, \mathrm{~F}^{6.44}\right.$, and $\mathrm{W}^{6.48}$ ), positioned deep in the TMHs [72] (Figure 3). The first-generation $\mathrm{H}_{1} \mathrm{R}$ antagonist doxepin sits deep in the ligand-binding pocket and directly interacts with $\mathrm{W}^{6.48}$, a highly conserved key residue required for GPCR activation, which is stabilized upon antagonist binding. The amine moiety of doxepin interacts with residue $\mathrm{D}^{3.32}$ present in all aminergic GPCRs. Both the upper and lower aromatic regions accommodate the butterfly-shaped hydrophobic aromatic moieties of doxepin. All these three regions were investigated to unravel $\mathrm{H}_{1} \mathrm{R}$ molecular determinants and visualize the binding hotspots in order to determine high affinity $\mathrm{H}_{1} \mathrm{R}$ ligands. The combined WaterFLAP calculations (approach to predict the binding site waters to guide ligand docking) and site-directed mutagenesis studies emphasized the crucial role of residue 7.39 (Table 2), a highly variable residue in aminergic GPCRs, as a determinant of specific $\mathrm{N}$-methyl effects in amine ligand binding and responsible for stereo- and subtype-selectivity [72]. The second generation $\mathrm{H}_{1} \mathrm{R}$ antagonists containing 
unique carboxyl groups interacted with $\mathrm{K}^{5.39}$ and/or K179 $\mathrm{ECL2}$ in the anion-binding region of $\mathrm{H}_{1} \mathrm{R}$ leading to improved receptor pharmacology. This region is not conserved in other aminergic receptors illuminating the molecular basis of $\mathrm{H}_{1} \mathrm{R}$ antagonistic specificity and selectivity. The TM4 of the aminergic histamine $\mathrm{H}_{1} \mathrm{R}$ is also constricted, directing $\mathrm{W}^{4.56}$ (an important residue for $\mathrm{H}_{1} \mathrm{R}$-ligand binding, based on mutation studies) towards the aromatic ligand binding pocket.

$H_{1} R$ antagonists/inverse agonists

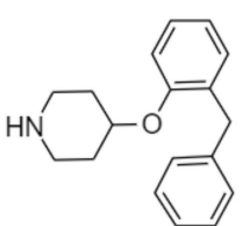

1. $\mathrm{K}_{\mathrm{i}}=6.3 \mathrm{nM}$<smiles>c1ccc(-c2nc3ccccc3nc2N2CCNCC2)cc1</smiles>

2. $\mathrm{K}_{i}=88.2 \mathrm{nM}$<smiles>OC(CN1CCC(Oc2ccc(F)cc2)CC1)c1cccs1</smiles>

3. $\mathrm{K}_{i}=106.1 \mathrm{nM}$

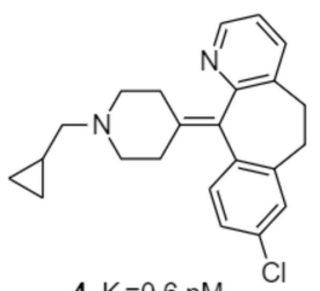

4. $\mathrm{K}_{\mathrm{j}}=0.6 \mathrm{nM}$

$\mathrm{H}_{2} \mathrm{R}$ antagonists/inverse agonists<smiles>Cc1nc(N)sc1CCCNC(=N)NCNC(=N)NCCCc1sc(N)nc1C</smiles>

5. $\mathrm{K}_{\mathrm{i}}=47 \mathrm{nM}$

$\mathrm{H}_{3} \mathrm{R}$ antagonists/inverse agonists<smiles>CCCN1CCC(COc2nc3ccc(Cl)cc3c3c2CCCN3)CC1</smiles>

6. $\mathrm{K}_{f}=41.6 \mathrm{nM}$<smiles>CN1CCN(CCCN(C)C(=O)c2cc3ccc(Cl)cc3[nH]2)CC1</smiles>

7. $\mathrm{K}_{\mathrm{f}}=0.49 \mu \mathrm{M}$<smiles>CCN1CCN(C(=O)c2ccc(-c3nc4ccccc4s3)s2)CC1</smiles>

8. $\mathrm{K}_{l}=38.2 \mathrm{nM}$<smiles>O=C(c1cccc(N=Nc2ccc(OC3CC([NH+]4CCCCC4)C3)cc2)c1)N1CCCC1</smiles>

9. $\mathrm{K}_{j}=1.74 \mathrm{nM}$<smiles>CN1c2ccc(OCCCN3CCCCCC3)cc2CN2CCc3ccccc3C21</smiles>

10. $\mathrm{K}_{\mathrm{i}}=17.6 \mathrm{nM}$<smiles>CCCNC1CN(c2ccnc(N)n2)C1</smiles>

11. $\mathrm{K}_{\mathrm{i}}=2.9 \mathrm{nM}$

$\mathrm{H}_{4} \mathrm{R}$ antagonists/inverse agonists<smiles>c1ccc(C(OCCCc2c[nH]cn2)c2nc3ccccc3s2)cc1</smiles>

12. $\mathrm{K}_{i}=1.1 \mathrm{nM}$<smiles></smiles>

13. $\mathrm{K}=22 \mathrm{nM}$<smiles>CN1CCN(c2ncnc3c2oc2ccccc23)CC1</smiles>

14. $\mathrm{K}_{\mathrm{i}}=144 \mathrm{nM}$<smiles>CN1CCN(c2nc(N)nc(CC3CCCCC3)n2)CC1</smiles>

15. $\mathrm{K}_{\mathrm{f}}=160 \mathrm{nM}$

Figure 2. The most potent ligands targeting HRs discovered through diverse virtual screening and docking approaches in 2014-2020 and their biological activities. 
Table 2. Residues (in B-W numbering scheme) of HR subtypes involved in the binding of ligands studied in particular papers.

\begin{tabular}{|c|c|c|c|c|c|}
\hline \multirow{2}{*}{ Residue } & \multicolumn{4}{|c|}{ Residues } & \multirow{2}{*}{ Reference } \\
\hline & $\mathrm{H}_{1} \mathrm{R}$ & $\mathrm{H}_{2} \mathbf{R}$ & $\mathrm{H}_{3} \mathrm{R}$ & $\mathrm{H}_{4} \mathrm{R}$ & \\
\hline 2.50 & & & D80 & & {$[49,54]$} \\
\hline 2.61 & N84 & S75 & Y91 & $\mathrm{Y} 72$ & {$[26,55-64]$} \\
\hline 2.62 & I85 & & & & [31] \\
\hline 2.64 & Y87 & Y78 & Y94 & H75 & {$[55,60,63]$} \\
\hline 2.65 & L88 & & & & [55] \\
\hline ECL1 & W93 & & & & [65] \\
\hline 3.28 & W103 & Y94 & W110 & W90 & {$[54,55,59,62,63,66-68]$} \\
\hline 3.29 & L104 & T95 & L111 & & {$[55,57,62,66]$} \\
\hline 3.32 & D107 & D98 & D114 & D94 & {$[6,9,12,22-26,31,48,49,51-60,62-64,66,69-86]$} \\
\hline 3.33 & Y108 & V99 & Y115 & Y95 & $\begin{array}{c}{[6,12,22,24,26,31,51,52,55-57,59,60,62-64,66,68-72,75-} \\
80,82-84,86-92]\end{array}$ \\
\hline 3.36 & S111 & C102 & C118 & $\mathrm{C} 98$ & {$[6,12,31,48,57,64,66,76,79,88,90]$} \\
\hline 3.37 & T112 & & T119 & T99 & {$[12,31,51,57,64,73,78,88]$} \\
\hline 3.40 & $\mathrm{I} 115$ & I106 & A122 & V102 & {$[31,55,57,64,76,78,88,89]$} \\
\hline 3.41 & F116 & & & & [31] \\
\hline 4.56 & W158 & L149 & L166 & V146 & {$[9,31,52,55-57,63,64,66,72,73,76,78,90]$} \\
\hline 4.57 & & & Y167 & N147 & {$[6,12,53,93]$} \\
\hline 4.60 & & S153 & & M150 & {$[6,12,77]$} \\
\hline 4.61 & & $\mathrm{I} 154$ & & & [66] \\
\hline ECL2 & & N159 & E175 & & {$[49,66]$} \\
\hline ECL2 & H167 & & & & [55] \\
\hline ECL2 & R175 & & & & [65] \\
\hline ECL2 & R176 & & & & {$[55,65,69]$} \\
\hline ECL2 & & $\mathrm{T} 171$ & & & [77] \\
\hline ECL2 & D178 & & & S162 & {$[12,55,83]$} \\
\hline ECL2 & K179 & & H187 & E163 & {$[12,55,56,58,59,65,66,69,77,82,83]$} \\
\hline ECL2 & C180 & $\mathrm{C} 174$ & & C164 & {$[12,55,66]$} \\
\hline ECL2 & E181 & K175 & Y189 & E165 & {$[12,51,55,66-68,80,85,88,91,94]$} \\
\hline ECL2 & T182 & V176 & A190 & P166 & {$[12,48,55,62,66,77,80,94,95]$} \\
\hline ECL2 & D183 & Q177 & E191 & & {$[48,49,54,70,77,94,95]$} \\
\hline ECL2 & F184 & $\widehat{V} 178$ & F192 & F168 & {$[6,12,26,31,53,54,66,77,78,80,82,96]$} \\
\hline ECL2 & Y185 & & F193 & F169 & {$[12,31,55,57-59,62,68,69,77,80,82,83,89]$} \\
\hline ECL2 & & & Y194 & & {$[62,94,95]$} \\
\hline ECL2 & & & W196 & & {$[62,94,95]$} \\
\hline 5.38 & F190 & Y182 & F198 & $\mathrm{I} 174$ & {$[6,12,31,51,57,59,63,66,88,90,94]$} \\
\hline 5.39 & K191 & G183 & L199 & L175 & {$[6,12,26,31,53,55-57,62,63,66,69-71,87]$} \\
\hline 5.42 & T194 & D186 & A202 & T178 & {$[6,12,56,57,63,64,66,75,77,79,82,85,87,90]$} \\
\hline 5.43 & A195 & G187 & S203 & S179 & {$[12,26,31,55,57,63,64,66,82,83,87]$} \\
\hline 5.46 & N198 & T190 & E206 & E182 & {$[6,12,23-26,31,49-53,57-61,63-69,75-77,79-83,85-95]$} \\
\hline 5.47 & F199 & & F207 & F183 & {$[9,12,26,31,55,64,67,72,76,90]$} \\
\hline 6.44 & F424 & & F367 & V184 & {$[66,72,76,82,90]$} \\
\hline 6.48 & W428 & W247 & W371 & W316 & $\begin{array}{c}{[9,12,24,26,31,49,51-53,55-} \\
58,61,63,66,67,72,73,75,76,79,80,84,87,89-91,94,97]\end{array}$ \\
\hline 6.51 & Y431 & $\mathrm{Y} 250$ & Y374 & Y319 & $\begin{array}{c}{[6,12,22,24,31,48,49,51-53,55-57,59-61,63,65-67,69-} \\
73,75-77,79-83,85-89,91,92,94,95,98]\end{array}$ \\
\hline 6.52 & F432 & F251 & T375 & S320 & {$[9,12,31,55,56,63,66,72,73,75,76,83,84,87]$} \\
\hline 6.55 & F435 & F254 & M378 & T323 & {$[9,12,31,53,55-57,66,72,75,76,83,84]$} \\
\hline 6.58 & $\mathrm{I} 438$ & & R381 & L326 & {$[12,55,61,62,65,80,89]$} \\
\hline 6.59 & A439 & & & S327 & {$[12,55]$} \\
\hline ECL3 & K442 & & & S330 & {$[12,55]$} \\
\hline ECL3 & N443 & & & S331 & {$[12,55,65,69,83]$} \\
\hline 7.35 & $\mathrm{H} 450$ & E270 & Y394 & Y340 & {$[48,55,56,60,62,67-69,73,74,77,83,89]$} \\
\hline 7.39 & $\mathrm{I} 454$ & $\mathrm{~L} 274$ & F398 & F344 & {$[6,23,24,51-53,55,57,59,60,62,63,66,68,72,76,84]$} \\
\hline 7.42 & G457 & G277 & L401 & Q347 & {$[6,23,24,26,31,52,53,57,58,63,79,80,82,86]$} \\
\hline 7.43 & Y458 & $\mathrm{Y} 278$ & W402 & W348 & {$[23,24,26,31,54-56,58,63,66,71,72,80,87]$} \\
\hline
\end{tabular}




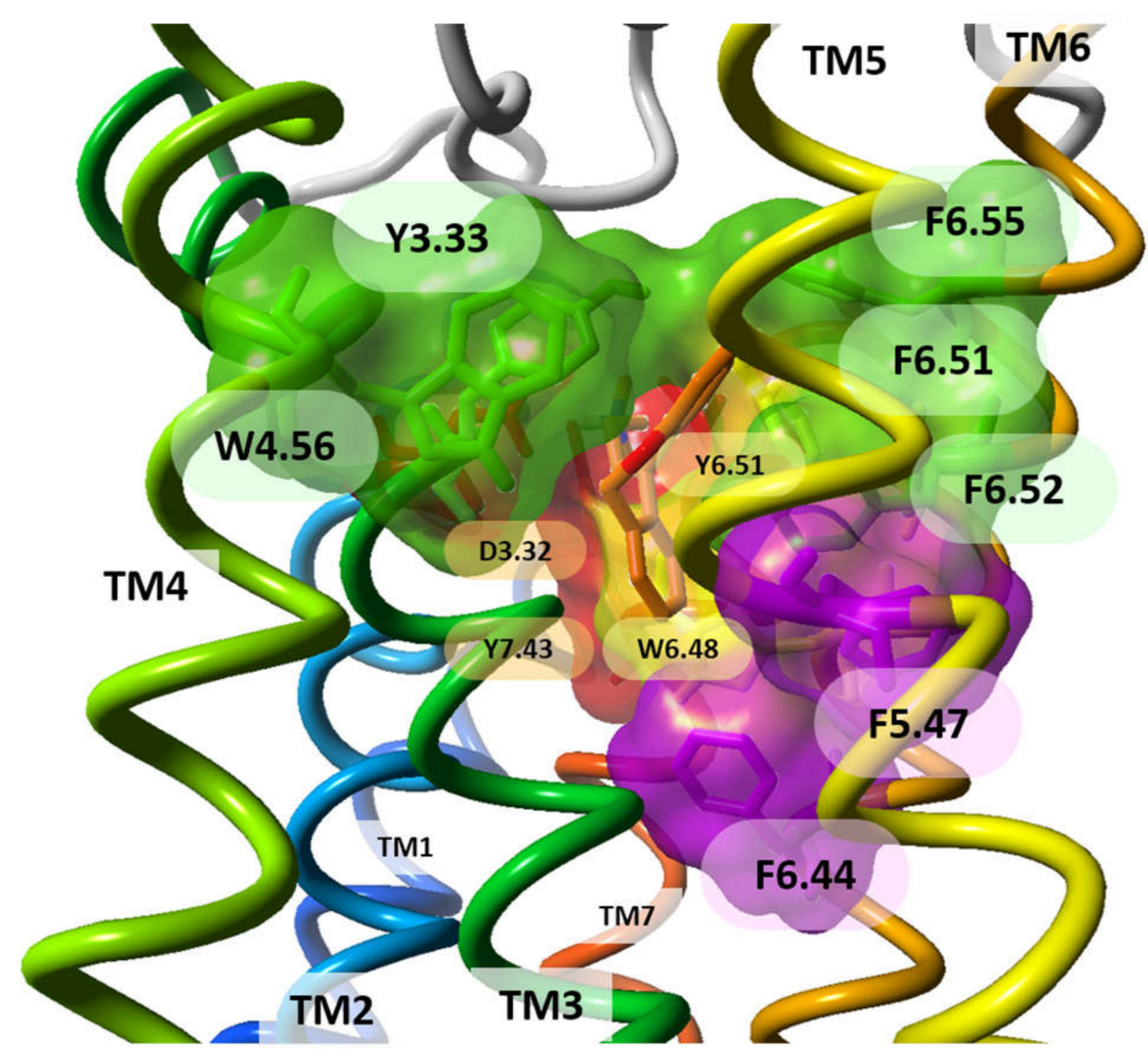

Figure 3. The areas of amino acids surrounding doxepin in the crystal structure of $\mathrm{H}_{1} \mathrm{R}$ : (red) the amine-binding region; (green) the upper aromatic region; (purple) the lower aromatic region; (yellow) the boundary amino acids participating in both amine-binding and aromatic regions. Doxepin is shown with its carbon atoms colored in orange. Side view of the receptor. TM helices are colored from blue (TM1) to red (TM7).

\subsection{2. $\mathrm{H}_{1} \mathrm{R}$ Targeted Ligands and Their Interactions in the Ligand-Binding Pocket} Receptor-Based in Silico Approaches Targeting $\mathrm{H}_{1} \mathrm{R}$

Several researchers have pioneered in the field of discovery of HR antagonists, especially those of $\mathrm{H}_{1} \mathrm{R}$, as its crystal structure has been available since 2011. Both mutagenesis and computational studies indicated the importance of interactions with $\mathrm{D}^{3.32}, \mathrm{Y}^{3.33}, \mathrm{~T}^{5.42}$, $\mathrm{N}^{5.46}, \mathrm{~W}^{6.48}, \mathrm{Y}^{6.51}, \mathrm{~F}^{6.52}$, and $\mathrm{F}^{6.55}$ in the orthosteric pocket for histamine and doxepin binding, and underlined the crucial electrostatic interaction with the side chain of $\mathrm{D}^{3.32}$ [75]. The other residues present in $\mathrm{H}_{1} \mathrm{R}$ and bound to the ligand were found to be K179 ${ }^{\mathrm{ECL} 2}$, $\mathrm{K}^{5.39}, \mathrm{H}^{7.35}$ and $\mathrm{Y}^{7.43}$ [56]. Multiple walker metadynamics-simulation protocol was used for the identification of the preferential binding mode of the physiological ligand histamine obtained from $92 \%$ of conformational ensembles [99]. Pose re-scoring of doxepin at $\mathrm{H}_{1} \mathrm{R}$ followed by multiple linear regression using Prime software of Schrodinger and MD simulations proved to be essential for predictive modeling of receptor-ligand interactions [84]. Enrichments in virtual screenings have been improved using Interaction Fingerprints (IFPs) such as the SYBYL software capturing atom-atom interactions and SPLIF (Structural Protein-Ligand Interaction Fingerprints) capturing fragment-fragment co-occurrences [5]. Also, the virtual screenings of fragment-like compounds, using consensus energy-based docking scoring approach including both IFP $(\geq 0.75)$ and PLANTS $(\leq-90)$, and the ionic interaction with residue $\mathrm{D}^{3.32}$ used as a filter proved to be better than individual scoring algorithms with increased hit rate of $73 \%$. These attempts led to the efficient identification of chemically novel $\mathrm{H}_{1} \mathrm{R}$ antagonists (ECFP-4 similarity cut-off of 0.4 ) with nanomolar affinities and potencies such as Compounds 1-3 (Figure 2) [9,72]. 
To demonstrate differences in the orthosteric binding sites of histamine receptors we have docked doubly protonated histamine to explore strong binding modes. The protonation state and the chosen pose of histamine are used for illustrative purposes only. The ligand histamine has been selected since the histamine molecule is small, so it does not change the binding site much, and is able to bind to all histamine receptors. The most likely binding mode of doubly protonated histamine in $\mathrm{hH}_{1} \mathrm{R}$ is shown in Figure 4 .

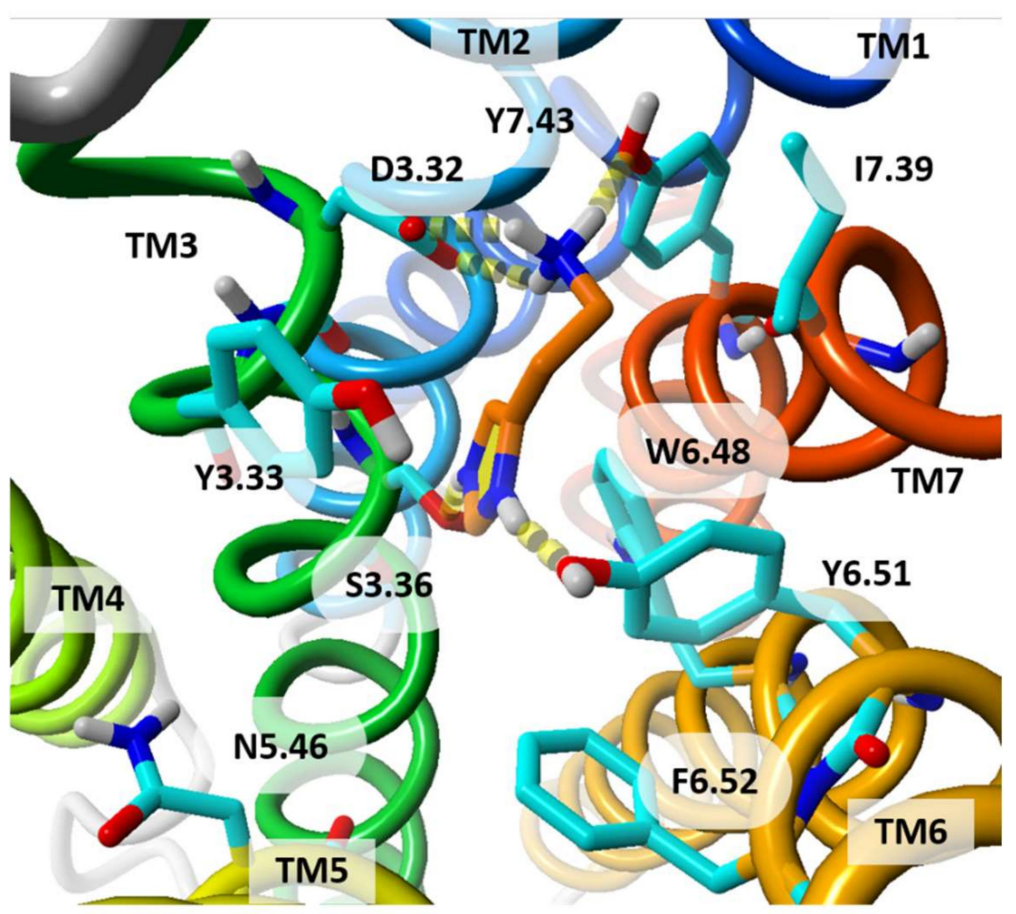

Figure 4. Histamine molecule docked to the crystal structure of $\mathrm{hH}_{1} \mathrm{R}$. The histamine is doubly positively charged. The amine group is bound to $\mathrm{D}^{3.32}$ and $\mathrm{Y}^{7.43}$, and the imidazole ring to $\mathrm{S}^{3.36}$ and $\mathrm{Y}^{6.51}$. The residue numbers are shown in Ballesteros-Weinstein numbering scheme. Histamine is shown with its carbon atoms colored in orange. View from extracellular side. TM helices are colored from blue (TM1) to red (TM7).

Diverse multi-target compounds, including indolecarboxamides and alkyl/aryl piperidyl indoles, were reported as $\mathrm{H}_{1} \mathrm{R}$, serotonin-5HT and CCR2 antagonists $[65,69]$ while phenothiazines (promethazine, chlorpromazine, 2-chlorophenothiazine, thioridazine, trifluoperazine) were reported to be MRGPRX2 activators and $\mathrm{H}_{1} \mathrm{R}$ antagonists [100]. Chlorpromazine has high affinity to other GPCRs including dopamine, norepinephrine and muscarinic receptors [101,102]. The polypharmacology effect [103,104] of such ligands highlights the importance of other GPCRs, not only $\mathrm{H}_{1} \mathrm{R}$, as potential templates for homology modeling of HRs. Indolecarboxamides were reported to form hydrogen bonds with $\mathrm{N} 443^{\mathrm{ECL} 3}, \mathrm{R} 176^{\mathrm{ECL} 2}$, and $\mathrm{I}^{6.58}$ [65] while alkyl/aryl piperidyl indole formed electrostatic interactions with conserved $Y^{6.51}$ residue [69]. Several other compounds have been docked to the $\mathrm{H}_{1} \mathrm{R}$ structure such as aminomethylenepyrimidine-2,4,6-triones, $\mathrm{N}^{1}$ alkyltheobromine, N-methylanthranilates, azabicyclic isoxazoline acylhydrazones, substituted tetrazole-incorporated quinoline derivative, synthesized rupatadine and desloratadine analogues $[70,73,76,105]$. Elbayaa [70] designed a series of substituted aminomethylenepyrimidine-2,4,6-trione derivatives generated from a four-featured pharmacophore model with an aromatic or $\pi$-ring system, hydrophobic group, a H-bond donor and a $\mathrm{H}$-bond acceptor group derived from five $\mathrm{H}_{1} \mathrm{R}$ antagonists and validated this model using six other $\mathrm{H}_{1} \mathrm{R}$ antagonists. These antagonists were mapped on the pharmacophore model with a good fitting score and low RMSD and then were docked using Molegro Virtual Docker on the $\mathrm{H}_{1} \mathrm{R}$ model obtained from SWISS-MODEL. They were reported to be a promising template for designing novel non-sedating $\mathrm{H}_{1} \mathrm{R}$ antihistaminic agents [70]. Docking studies, 
using AutoDock, showed that derivatives of $\mathrm{N}^{1}$-alkyltheobromine, which exhibited $\mathrm{H}_{1} \mathrm{R}$ antihistaminic activity comparable to doxepin and less CNS depressant side effects than olapatadine, interacted electrostatically and formed hydrogen bonds with residues $\mathrm{D}^{3.32}$, $\mathrm{Y}^{3.33}, \mathrm{~S}^{3.36}, \mathrm{~T}^{3.37}, \mathrm{~K}^{5.39}$ and $\mathrm{Y}^{6.51}$ [71]. In one study, quinoline derivative (QS-15), astemizole and diclofenac sodium have been shown to interact with residues $\mathrm{D}^{3.32}, \mathrm{~W}^{6.48}$ and $\mathrm{F}^{6.52}$ [73]. Additionally, although the fragment VUF13816 is structurally different from the reported $\mathrm{H}_{1} \mathrm{R}$ ligands obtained from virtual screening, it was observed to have similar contacts to the receptor as doxepin (residues $\mathrm{H}^{7.35}$ and $\mathrm{D}^{3.32}$ ). A series of three fluorescent ligands was designed based on this small fragment that retained similar affinity towards $\mathrm{H}_{1} \mathrm{R}$ as the parent compound [74].

In another study [55], fexofenadine, a potent non-sedative third-generation $\mathrm{hH}_{1} \mathrm{R}$ antagonist was proved to be beneficial in treating $\mathrm{H}_{1} \mathrm{R}$ related allergic conditions of dogs and cats. In this study, the homology models of dog and cat $\mathrm{H}_{1} \mathrm{R}$ isoforms were built and fexofenadine was subsequently docked to human, dog and cat $\mathrm{H}_{1} \mathrm{R}$. In total, it interacted with 23 residues in all the three receptors, and the most crucial molecular determinants in $\mathrm{hH}_{1} \mathrm{R}$ were $\mathrm{W}^{6.48}, \mathrm{~F}^{6.52}, \mathrm{Y}^{3.33}, \mathrm{~N}^{5.46}$ and $\mathrm{T}^{5.42}$ [55]. The potential phytochemical inhibitors targeting both $\mathrm{H}_{1} \mathrm{R}$ and cytosolic phospholipase $\mathrm{A}_{2}$, with good pharmaceutical druglike properties, such as $3^{\prime}, 4^{\prime}, 7$-trihydroxyflavone, calycosin, geraldone, licoflavanone and epidistenin were reported to interact with $\mathrm{D}^{3.32}, \mathrm{~S}^{3.36}, \mathrm{Y}^{6.51}, \mathrm{H}^{7.35}$ as well as $\mathrm{T} 182^{\mathrm{ECL} 2}$ and D183 ${ }^{\mathrm{ECL} 2}$ [48]. Also, the anti-allergic and anti-inflammatory potential of phytocomponents was analyzed by computational docking analysis on $\mathrm{H}_{1} \mathrm{R}[87,97,106]$. The examined compounds included: $\beta$-pinene, thymol and carvacrol, present in the Siddha formulation Oma Legium, the standard cetrizine and bioactive phytotherapeutics such as ascorbic acid, $\beta$ sitosterol, sesquiterpene, and tocopherolpresent in the medicinal herb Corallocarpus epigaeus, as well as flavones like kaempferol and kaempferol-3-glucuronide found in Centratherum punctatum along with desloratadine as a reference standard. The flavones and desloratadine showed similar ligand-protein interactions with residues $\mathrm{Y}^{6.51}$ and $\mathrm{F}^{6.52}$ [87]. Curcumin has also been shown to possess $\mathrm{H}_{1} \mathrm{R}$ antagonistic activity [56]. About 22 synthesized rupatadine and desloratadine analogues, including Compound 4 (Figure 2), were docked to $\mathrm{H}_{1} \mathrm{R}$ and, guided by docking studies, the steric constraints within the binding pocket were found to explain the observed differences in affinity of ligands. The limiting residues were $\mathrm{I}^{7.39}$ and $\mathrm{Y}^{7.43}$ located next to the amine-binding region [98]. Methyl (MMA), propyl (PMA) and isopropyl (IMA) $\mathrm{N}$-methylanthranilate, originally found in the leaf essential oil of Choisya ternata, were reported to establish interactions with $\mathrm{D}^{3.32}, \mathrm{Y}^{3.33}, \mathrm{~S}^{3.36}, \mathrm{I}^{3.40}, \mathrm{~W}^{4.56}$, $\mathrm{N}^{5.46}, \mathrm{~F}^{5.47}, \mathrm{~F}^{6.44}, \mathrm{~W}^{6.48}, \mathrm{Y}^{6.51}, \mathrm{~F}^{6.52}, \mathrm{~F}^{6.55}$ and $\mathrm{I}^{7.39}$ [76]. In 2020, a set of 35 antihistamines was designed using cloperastine as the core molecule in docking and molecular dynamics studies, however, no experimental binding studies were performed [107]. Another study involving in silico design, synthesis, ADME profiling and evaluation of antagonistic effects of 1,8-naphthyridine-3-carboxylic acid analogues was carried out using chlorpheniramine as the standard drug. Ligand dockings using Auto Dock Vina elucidated the crucial interactions in the binding pocket of $\mathrm{H}_{1} \mathrm{R}$, involving residues $\mathrm{D}^{3.32}, \mathrm{Y}^{3.33}, \mathrm{~S}^{3.36}$ and $\mathrm{Y}^{6.51}$, for the ligands possessing satisfactory ADME profiles [108].

\section{Ligand-Based Computational Approaches in Search for Potential $\mathrm{H}_{1} \mathrm{R}$ Ligands}

Fragment-based drug discovery proved to be a propitious approach for the development of novel chemically and therapeutically active leads. The identification of small fragment-like biologically active dual $\mathrm{H}_{1} \mathrm{R} / \mathrm{H}_{4} \mathrm{R}$ antagonists has been made possible through prospective ligand-based virtual screening (LBVS) using 14 different chemical similarity descriptors and consensus scoring approaches [27]. It was evident through this study that the performance of the similarity descriptors decreases with decreasing self-similarity of the actives. Also, the Molecular ACCess System (MACCS) turned out to be one of the three best performing similarity descriptors for $\mathrm{H}_{1} \mathrm{R}$ and $\mathrm{H}_{4} \mathrm{R}$, while piDAPH3 and piDAPH4 being the worst. Certain consensus scoring methods achieve better enrichments, with best results in both the max-value or ranked-by-vote consensus 
methods as became evident in study of $\mathrm{H}_{1} \mathrm{R}$ and $\mathrm{H}_{4} \mathrm{R}$ virtual screening enrichments [27]. Even the ligand-based comparative molecular similarity indices analysis (CoMSIA) model $\left(Q^{2}=0.525, R^{2}\right.$ ncv $=0.891, R^{2}$ pred $\left.=0.807\right)$, using 129 reported $H_{1} R$ antagonists, had good predictive quality for predicting the bioactivities of new chemicals. Subsequent molecular docking and simulation of these reported antagonists unraveled their binding modes in the active site of $\mathrm{H}_{1} \mathrm{R}$ [64].

\subsection{Computational Studies of $\mathrm{H}_{2} \mathrm{R}$ and Its Ligands}

Although $\mathrm{H}_{2} \mathrm{R}$ is a promising drug target, the computational modeling of $\mathrm{H}_{2} \mathrm{R}$ (UniProt id:P25021, 359 amino acids) has not been studied extensively due to the lack of the crystal structure which hampered the drug discovery efforts. This shortcoming makes development of protein models for structure-based approach a necessity [109]. The quality of the generated homology models largely depends on the selection of template(s) and the sequence alignment while robustness is judged on the basis of their ability to differentiate between known actives and decoys [110,111].

\subsubsection{Homology Modeling of $\mathrm{H}_{2} \mathrm{R}$}

Homology modeling that combines multiple templates usually yields better receptor structures for drug discovery processes. Since $\mathrm{hH}_{1} \mathrm{R}$ and $\mathrm{hH}_{2} \mathrm{R}$ have low sequence similarity and identity, the $\beta_{1} \mathrm{AR}$ (PDB id:4BVN), $\mathrm{h} \beta_{2} \mathrm{AR}$ (PDB id:2RH1), $\mathrm{hD} \mathrm{D}_{3} \mathrm{R}$ (PDB id:3PBL) and $\mathrm{hH}_{1} \mathrm{R}$ (PDB id:3RZE) were chosen as templates, depending upon TM similarities and identities for $\mathrm{H}_{2} \mathrm{R}$ homology modeling, as for example, in the study of Saxena et al. [66]. Krzan et al. [85] generated a $\mathrm{H}_{2} \mathrm{R}$ homology model employing multiple webservers and programs: I-TASSER [112], MODELLER [113], SWISS MODEL [114] and Pyre2 [115] using the following templates: $\mathrm{hH}_{1} \mathrm{R}$ (PDB id:3RZE), the neurokinin 1-receptor (PDB id:2KS9), human $\beta_{2}$-adrenergic receptor (PDB id:2RH1), human $\beta_{1}$-adrenoceptor (PDB id:4BVN), and $\mathrm{M}_{3}$ muscarinic acetylcholine receptor (PDB id:4DAJ). The best model was selected using the statistics for non-bonded interactions generated by the ERRAT tool [116] and stereochemical properties obtained from PROCHECK [117]. Chaudhary et al. [118] screened a range of phytochemicals present in Ficus religiosa for binding to $\mathrm{hH}_{2} \mathrm{R}$. For this study a homology model of $\mathrm{hH}_{2} \mathrm{R}$ was generated on the basis of similarity search using four structures of $\beta_{1}$-adrenergic receptor (PDB ids:2VT4, 2Y00, 4BVN and 5A8E) as templates. In another study, a template of $\beta_{1}$-AR (PDB id:2VT4) was used for homology modeling and a model quality was assessed by Ramachandran plot while AutoDock was used for docking of compounds [119]. Recently, Boddupally et al. [120] also generated a $\mathrm{hH}_{2} \mathrm{R}$ model based on a $\beta_{1}$-AR template (PDB id:6H7J) using MODELLER and evaluated it by PROCHECK and Ramachandran plot. The modeling was followed by docking of twenty natural flavonoid compounds to the receptor in AutoDock. In the above three studies only $\beta_{1}$-AR was used as a template so the modeled structure of $\mathrm{H}_{2} \mathrm{R}$ showed some limitations in model quality.

\subsection{2. $\mathrm{H}_{2} \mathrm{R}$-Targeted Ligands and Their Interactions at $\mathrm{H}_{2} \mathrm{R}$ Active Site}

In an effort to design, develop and optimize selective $\mathrm{H}_{2} \mathrm{R}$ as well as dual $\mathrm{H}_{1} \mathrm{R}$ and $\mathrm{H}_{2} \mathrm{R}$ ligands, molecular docking using the Schrodinger package provided insights on how to rationalize the binding of octahydropyrazinopyridoindole class of compounds [66]. Additionally, docking the standard $\mathrm{H}_{2} \mathrm{R}$ antagonists such as metiamide, cimetidine, ranitidine and famotidine to the homology modeled $\mathrm{hH}_{2} \mathrm{R}$ enabled comparison of properties of selective ligands of $\mathrm{H}_{1}$ and $\mathrm{H}_{2}$ receptors. It has been found that hydrophobic regions are important for selective $\mathrm{hH}_{1} \mathrm{R}$ antagonists whereas polar features for selectivity of $\mathrm{hH}_{2} \mathrm{R}$ antagonists. However, the hydrophobic interaction in vicinity of polar region was also discriminating for $\mathrm{hH}_{2} \mathrm{R}$ ligands due to the presence of $\mathrm{V}^{3.33}$ residue in $\mathrm{H}_{2} \mathrm{R}$ instead of $\mathrm{Y}^{3.33}$ in $\mathrm{H}_{1} \mathrm{R}$ and other histamine receptors. Details of the orthosteric binding site of homology model of $\mathrm{hH}_{2} \mathrm{R}$ are shown in Figure 5. Analysis of the residue properties further confirmed TM5 to be the most dissimilar region between $\mathrm{hH}_{1} \mathrm{R}$ and $\mathrm{hH}_{2} \mathrm{R}$, followed by TM6 and TM3. 
A mutagenesis study revealed that the residue $\mathrm{D}^{3.32}$ is vital for histamine and antagonist binding, while $\mathrm{D}^{5.42}$ and $\mathrm{T}^{5.46}$ are important for the selectivity and kinetics of histamine binding. The presence of $\mathrm{V}^{3.33}$ and $\mathrm{D}^{5.42}$ in $\mathrm{hH}_{2} \mathrm{R}$ introduces a bulkier space and negatively charged environment at this position as compared to $\mathrm{Y}^{3.33}$ and $\mathrm{T}^{5.42}$ in $\mathrm{hH}_{1} \mathrm{R}$, respectively. Other important hydrophobic residues, $\mathrm{W}^{6.48}, \mathrm{Y}^{6.51}, \mathrm{~F}^{6.52}$ and $\mathrm{F}^{6.55}$, are the same in both $\mathrm{H}_{1} \mathrm{R}$ and $\mathrm{H}_{2} \mathrm{R}$. The representative class of $\mathrm{hH}_{2} \mathrm{R}$ antagonists was found to form hydrogen bonds with $\mathrm{D}^{3.32}, \mathrm{D}^{5.42}, \mathrm{Y}^{6.51}$, and $\mathrm{N} 159^{\mathrm{ECL} 2}$ and hydrophobic contacts with the aromatic triad in $\mathrm{H}_{2} \mathrm{R}\left(\mathrm{W}^{6.48}, \mathrm{Y}^{6.51}\right.$, and $\left.\mathrm{F}^{6.52}\right)$. Analysis of the structure-based pharmacophore model for $\mathrm{H}_{1} \mathrm{R}$ and $\mathrm{H}_{2} \mathrm{R}$ indicates that hydrophobic features are important for selective $\mathrm{H}_{1} \mathrm{R}$ antagonism while polar groups are preferable for selective $\mathrm{H}_{2} \mathrm{R}$ antagonism.

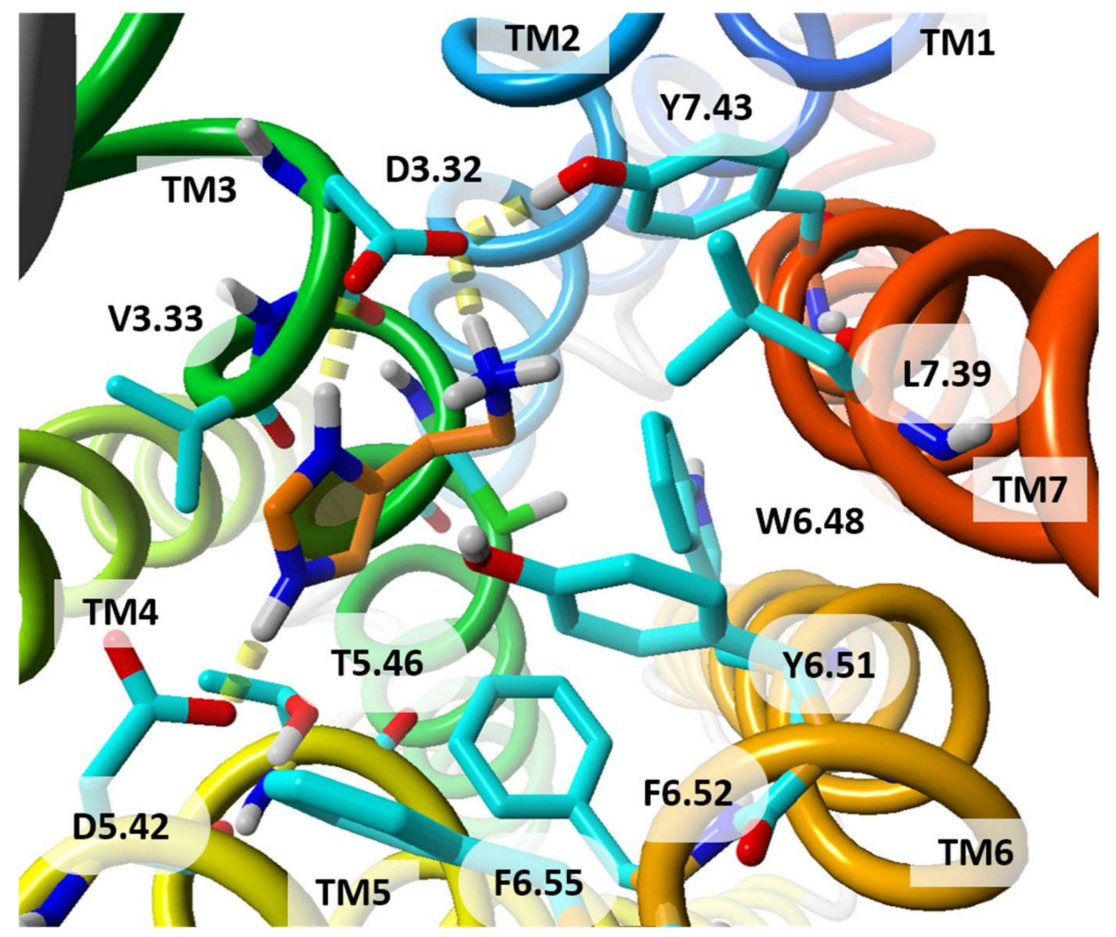

Figure 5. Histamine molecule docked to the homology model of $\mathrm{hH}_{2} \mathrm{R}$. The histamine is doubly positively charged. Both charged moieties of histamine are bound to $D^{3.32}$. The imidazole ring is additionally bound to $\mathrm{D}^{5.42}$. The residue numbers are shown in Ballesteros-Weinstein numbering scheme. Histamine is shown with its carbon atoms colored in orange. View from extracellular side. TM helices are colored from blue (TM1) to red (TM7).

Histamine docked to the optimized model of $\mathrm{H}_{2} \mathrm{R}$ asserted the importance of three crucial residues $\mathrm{D}^{3.32}, \mathrm{D}^{5.42}$ and $\mathrm{Y}^{6.51}$ for histamine binding. A proton transfer from the charged ethylamino group of histamine to $\mathrm{D}^{3.32}$ allowed $\mathrm{K} 175^{\mathrm{ECL} 2}$ to undergo large conformational change and approach the $\mathrm{D}^{3.32}$ residue. Additionally, from performed quantum-chemical calculations, it was evident that deuteration increased affinity of histamine towards $\mathrm{H}_{2} \mathrm{R}$ binding [85]. Pockes et al. [77] performed studies on dimeric hetarylpropylguanidine-type derivatives which were docked to $\mathrm{H}_{2} \mathrm{R}$ while the monovalent ligands were docked to $\mathrm{hH}_{3} \mathrm{R}$ and $\mathrm{hH}_{4} \mathrm{R}$. Docking studies were followed by $30 \mathrm{~ns}$ MD simulations and the lowest free-energy conformations of compounds formed the strongest $\mathrm{H}$-bond contacts with the residues of the orthosteric binding site: $\mathrm{D}^{3.32}$ and $\mathrm{D}^{5.42}$ in $\mathrm{hH}_{2} \mathrm{R} ; \mathrm{D}^{3.32}$ in $\mathrm{hH}_{3} \mathrm{R}$; and $\mathrm{D}^{3.32}$, $\mathrm{E}^{5.46}, \mathrm{E} 163^{\mathrm{ECL} 2}$ and $\mathrm{T}^{5.42}$ in $\mathrm{hH} 4 \mathrm{R}$. The residue $\mathrm{D}^{5.42}$ accounts for $\mathrm{hH}_{2} \mathrm{R}$ selectivity since it is not present in other histamine subtypes. Different steric effects of residues enclosing the orthosteric binding pocket may be at play since residues $\mathrm{V}^{3.33}, \mathrm{~V} 176^{\mathrm{ECL} 2}-\mathrm{Q} 177^{\mathrm{ECL} 2}$ of $\mathrm{hH}_{2} \mathrm{R}$ are less voluminous when compared to $\mathrm{Y}^{3.33}, \mathrm{~F} 184^{\mathrm{ECL} 2}-\mathrm{Y} 185^{\mathrm{ECL} 2}$ of $\mathrm{hH}_{1} \mathrm{R} ; \mathrm{Y}^{3.33}$, $\mathrm{F} 192^{\mathrm{ECL} 2}-\mathrm{F} 193^{\mathrm{ECL} 2}$ of $\mathrm{hH} \mathrm{H}_{3} \mathrm{R}$; and $\mathrm{Y}^{3.33}, \mathrm{~F} 168^{\mathrm{ECL} 2}-\mathrm{F} 169^{\mathrm{ECL} 2}$ of $\mathrm{hH}_{4} \mathrm{R}$. During the study, it was observed that dimeric compounds showed better affinity towards $\mathrm{hH}_{2} \mathrm{R}$ while monomeric 
ligands showed better affinity towards $\mathrm{hH}_{3} \mathrm{R}$ and $\mathrm{hH}_{4} \mathrm{R}$ [77]. A representative of the former ligands is Compound 5 shown in Figure 2.

\subsection{Computational Studies on $\mathrm{H}_{3} \mathrm{R}$ and Its Ligands}

\subsubsection{Homology Modeling and Structural Aspects of $\mathrm{H}_{3} \mathrm{R}$}

The homology models of $\mathrm{H}_{3} \mathrm{R}$ (UniProt id:Q9Y5N1, 445 amino acids) were generated using a variety of templates starting from bovine rhodopsin (PDB id:1U19) [59]. In many studies the crystal structure of inactive $\mathrm{hH}_{1} \mathrm{R}$ (PDB id:3RZE) was used as a template for construction of the homology model of inactive $\mathrm{hH}_{3} \mathrm{R}$ since their sequences possess $31.4 \%$ identical residues $[57,58,79,81]$. The homology model of $\mathrm{H}_{3} \mathrm{R}$ was also built using $\mathrm{M}_{3}$ muscarinic acetylcholine receptor (PDB id: 4DAJ) [51,62,94,95]. Recently, researchers have described a $\mathrm{H}_{3} \mathrm{R}$ homology model taking the crystal structure of $\mathrm{M}_{2}$ muscarinic acetylcholine receptor as a template (PDB id: $3 \mathrm{UON}$ ) [67,121,122].

Jonczyk et al. [80] generated $\mathrm{H}_{3} \mathrm{R}$ homology models and used a hybrid assessment of these models based on knowledge-based scoring algorithm and two-step docking protocols including GOLD and Glide. The models also passed the quality analysis performed using BCL::Score, QMEAN and PSVS methods. A model built on the $\mathrm{M}_{3} \mathrm{R}$ template was preferred as compared to $\mathrm{H}_{1} \mathrm{R}$ or models built on mixed template alignments-they were characterized by significant differences in the most conformationally diversified ECL2 loop. Most models generated by MODELLER proved to be much better that those of SwissModel, I-TASSER and Jackal. In the best $\mathrm{H}_{3} \mathrm{R}$ model, 3-7 lock switch was considered as the interaction between the side chains $\mathrm{D}^{3.32}$ and $\mathrm{W}^{7.43}$, whose breakup can promote receptor activation. Additionally, the perpendicular position of residue $\mathrm{W}^{6.48}$, with respect to the helix axis forced by $\mathrm{L}^{7.42}$, favored recognition of $\mathrm{H}_{3} \mathrm{R}$-specific ligands and interaction with $\mathrm{E}^{5.46}$. Inactive conformation of $\mathrm{H}_{3} \mathrm{R}$ is maintained by residues $\mathrm{L}^{2.43}, \mathrm{~L}^{2.46}, \mathrm{I}^{3.43}, \mathrm{I}^{3.46}$ and $\mathrm{I}^{6.40}$ in the center of the receptor creating a hydrophobic barrier inside the receptor as in other GPCRs. Breakdown of this barrier is an important step in receptor activation and opens a gate for a continuous intrinsic water pathway [123,124].

The multiple template approach has also been applied for $\mathrm{H}_{3} \mathrm{R}$ homology modeling by using $\mathrm{H}_{1} \mathrm{R}$ (PDB id:3RZE), $\mathrm{M}_{2} \mathrm{R}$ (PDB id:3UON) and $\mathrm{M}_{3} \mathrm{R}$ (PDB id:4U15) as templates while ECL2 was built on $M_{2} R$ and $M_{3} R$. The models were ranked for possessing a crucial ionic protein-ligand interaction with residue $\mathrm{D}^{3.32}$ considered essential for ligand binding. It was also found that a conformation of residue $\mathrm{E}^{5.46}$ was more advantageous for ligand binding when it was pointing toward the binding pocket [52]. Another multiple template approach was employed by Hauwert et al. [60] for modeling $\mathrm{H}_{3} \mathrm{R}$ using $\mathrm{H}_{1} \mathrm{R}$ (PDB id:3RZE), $\mathrm{M}_{3} \mathrm{R}$ (PDB id:4U15), dopamine $\mathrm{D}_{3} \mathrm{R}$ (PDB id:3PBL), serotonin 5-HT $\mathrm{H}_{1 \mathrm{~B}} \mathrm{R}$ (PDB id:4IAR) and serotonin $5-\mathrm{HT}_{2 \mathrm{~B}} \mathrm{R}$ (PDB id:4IB4) receptors as templates and the MODELLER program.

\subsubsection{Ligands Targeting $\mathrm{H}_{3} \mathrm{R}$ and Their Interactions}

Like other GPCRs $\mathrm{H}_{3} \mathrm{R}$ is sodium sensitive, as it was made evident by using a mathematical model and MD simulations. It was also calculated that an $\mathrm{H}_{3} \mathrm{R}$ inverse agonist thioperamide binds to the orthosteric binding site of $\mathrm{hH}_{3} \mathrm{R}$ preferentially in a presence of $\mathrm{Na}^{+}$. In the presence of $\mathrm{Na}^{+}$, the positively charged imidazole moiety of thioperamide is located "above" the highly conserved residue $\mathrm{D}^{3.32}$ while in its absence the same moiety is located "below" $\mathrm{D}^{3.32}$ and directed toward the highly conserved $\mathrm{D}^{2.50}$, which forms the allosteric site for binding a sodium ion [58]. Thioperamide spans horizontally between two negatively charged residues $\mathrm{D}^{3.32}$ and $\mathrm{E}^{5.46}$ and the ligand is embedded in a pocket between helices TM3, TM5 and TM6 [58,59]. However, in a study [80] based on another template, M3 muscarinic receptor, thioperamide was docked vertically and interacted only with $\mathrm{D}^{3.32}$. There are two negatively charged residues, $\mathrm{D}^{3.32}$ and $\mathrm{E}^{5.46}$, in the orthosteric ligand binding pocket of $\mathrm{hH}_{3} \mathrm{R}$ (similarly to $\mathrm{hH}_{4} \mathrm{R}$ ). The former residue can bind to the protonated amine and is essential for interactions with agonists, including histamine. The second acidic binding point is created by $\mathrm{E}^{5.46}$ and adjacent tyrosine $\mathrm{Y}^{6.51}$. In a study by Jonczyk et al. [80], a series of amine antagonists including JNJ5207852 was docked to $\mathrm{hH}_{3} \mathrm{R}$ 
in vertical poses, and the protonated amines of these ligands were bound to $\mathrm{E}^{5.46}, \mathrm{Y}^{3.33}$ and $\mathrm{Y}^{6.51}$. It was also found that antagonist clobenpropit with protonated imidazole ring and isothiourea fragments, used both acidic points, $\mathrm{D}^{3.32}$ and $\mathrm{E}^{5.46}$, in the ligand binding space: imidazole interacted with $\mathrm{D}^{3.32}$ while isothiourea group, as a second protonated system, created a salt bridge with $\mathrm{E}^{5.46}$. It is in contrast to results obtained by Kim et al. [125] which employed a model of $\mathrm{hH}_{3} \mathrm{R}$ based on the human $\beta_{2}$-adrenergic receptor. Doubly charged clobenpropit was bound to $\mathrm{D}^{3.32}$ by its isothiourea group while the imidazole ring was bound to $\mathrm{E}^{5.46}$ and adjacent residues. Although it cannot be excluded that both poses are allowed, the future experimentally determined structures of histamine receptors with ligands will help docking studies enormously. Details of the orthosteric binding site of homology model of $\mathrm{hH}_{3} \mathrm{R}$ are shown in Figure 6.

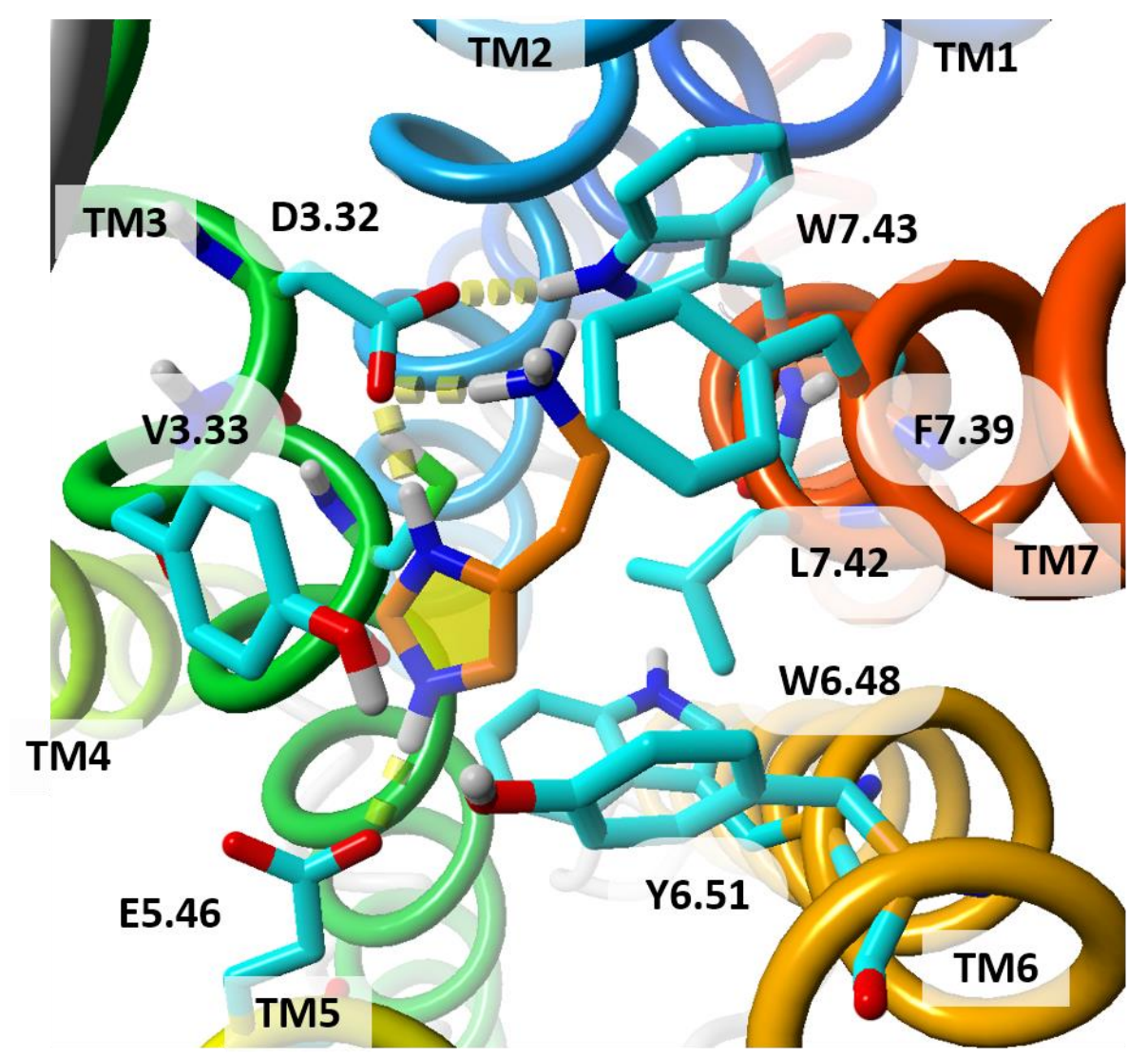

Figure 6. Histamine molecule docked to the homology model of $\mathrm{hH}_{3} \mathrm{R}$. The histamine is doubly positively charged. Both charged moieties of histamine are bound to $\mathrm{D}^{3.32}$. The imidazole ring is additionally bound to $\mathrm{E}^{5.46}$. The histamine hydrophobic linker is exposed toward hydrophobic residues $\mathrm{F}^{7.39}$ and $\mathrm{L}^{7.42}$. The residue numbers are shown in Ballesteros-Weinstein numbering scheme. Histamine is shown with its carbon atoms colored in orange. View from extracellular side. TM helices are colored from blue (TM1) to red (TM7).

Binding of more complex antagonists of $\mathrm{H}_{3} \mathrm{R}$ was possible by extending the ligands toward the external allosteric site residues, $R^{6.58}, Y^{7.35}$ and residues of the ECL2 loop (Y189, A190, F193 and Y194) as documented by Kumar et al. [62] for novel 4-aryl-6-methyl-5,6,7,8tetrahydroquinazolinamines as anti-obesity candidate drugs. In the study performed by the Gloriam group [50] the pharmacophores were constructed based on the residue-ligand fragments from the GPCR crystal structures. Thanks to the chemogenomic techniques that detect local similarities within the transmembrane binding pocket the whole scaffolds or ligands can be exchanged between targets. Performing such binding pocket comparisons is reasonable since many high-quality GPCR crystal structures with ligands are currently known. Using the above methodology for the fragment-based prospective virtual screening 
employing pharmacophores and molecular docking methodology they identified five novel neutral antagonists and one inverse agonist which were later confirmed in $\mathrm{G}_{\mathrm{q}}$-coupled pharmacological assay. They also found that residue $\mathrm{E}^{5.46}$ contributes to selectivity in $\mathrm{H}_{3} \mathrm{R}$ and $\mathrm{H}_{4} \mathrm{R}$ as compared to $\mathrm{H}_{1} \mathrm{Rs} / \mathrm{H}_{2} \mathrm{Rs}$ while residues at positions 2.64, 2.65, 5.42, 6.52, 6.55, and 7.36 confer $\mathrm{H}_{3} \mathrm{R} / \mathrm{H}_{4} \mathrm{R}$ selectivity [50].

Diverse screening protocols were applied for discovery of $\mathrm{H}_{3} \mathrm{R}$ targeted ligands including ligand-based approaches exploiting the similarities with respect to known actives as well as structure-based approaches exploiting the 3D-chemical interactions between ligands and the target structure [126]. Ghamari et al. [127] employed individual and combined hybrid structural similarity (FP2 fingerprint in 2D search, and also Electroshape and Spectrophores methods in 3D search) and pharmacophore-based approaches using the ZINCPharmer [128] and ZINC15 database followed by lead optimization, and identified potential drug-like anti- $\mathrm{H}_{3} \mathrm{R}$ ligands in micromolar and submicromolar activity range (including Compound 7 in Figure 2). The geometric center of residues $D^{3.32}, T^{3.37}$, Y189 ECL2, $\mathrm{F}^{5.38}, \mathrm{E}^{5.46}, \mathrm{~W}^{6.48}$, and $\mathrm{Y}^{6.51}$ was set as the center of the binding site. Docking of pitolisant and other ligands was performed with two distance constraints with $\mathrm{E}^{5.46}$ and $\mathrm{Y} 189^{\mathrm{ECL} 2}$ in GOLD. The phenyl ring of pitolisant was found sandwiched between $\mathrm{Y} 189^{\mathrm{ECL} 2}$ and $\mathrm{F}^{7.39}$ while piperidine nitrogen formed an ionic bond with $\mathrm{E}^{5.46}$ and a H-bond with $\mathrm{Y}^{3.33}$. Four-featured 3D-pharmacophore model comprising two hydrophobic regions, a positively ionizable moiety, and a hydrogen bond acceptor was generated from a docked pitolisant$\mathrm{H}_{3} \mathrm{R}$ complex using LigandScout [129]. The obtained hits possessed a common scaffold containing a basic moiety and an aromatic/hydrophobic moiety joined by a linker. The basic moiety interacted with $E^{5.46}$, the linker interacted with $Y^{3.33}$ and $Y^{6.51}$, while the hydrophobic/aromatic moiety was observed to interact with Y189 ${ }^{\mathrm{ECL} 2}$ and $\mathrm{F}^{7.39}$ [51,127]. In another study a quantitative structure-activity relationship (QSAR) model, employing a genetic algorithm coupled with partial least square and stepwise multiple linear regression methods, was used with two major descriptors: connectivity information and mean absolute charge in predicting $\mathrm{H}_{3} \mathrm{R}$ antagonistic activity. The additional molecular docking revealed the crucial role of residues $\mathrm{Y}^{3.33}, \mathrm{Y} 189^{\mathrm{ECL} 2}, \mathrm{~F} 193^{\mathrm{ECL} 2}, \mathrm{~L}^{5.39}, \mathrm{E}^{5.46}, \mathrm{~W}^{6.48}, \mathrm{Y}^{6.51}$, $\mathrm{M}^{6.55}, \mathrm{Y}^{7.35}$ and $\mathrm{F}^{7.39}$ in the interaction with $\mathrm{H}_{3} \mathrm{R}$ targeted ligands [91]. Schaller et al. [52] used a ligand-guided homology modeling strategy that resulted in identification of two $\mathrm{H}_{3} \mathrm{R}$ ligands with nanomolar affinity, including Compound 8 (Z27743747) in Figure 2. Pharmacophore models were generated by taking nine reported $\mathrm{H}_{3} \mathrm{R}$ antagonists and the virtual screening was performed using the Enamine library. The high-quality model of $\mathrm{H}_{3} \mathrm{R}$ was used for docking while keeping constraints focused on interactions with $\mathrm{D}^{3.32}$ and $E^{5.46}$. The obtained hits interacted with $D^{3.32}$ and $Y^{3.33}$ as well as with several other hydrophobic residues. The additional $\pi$-cation interaction with $\mathrm{F}^{7.39}$ was predicted to contribute to the superior $\mathrm{H}_{3} \mathrm{R}$ affinity of ligands [52].

The $\mathrm{H}_{3} \mathrm{R}$ antagonists have been classified as imidazole- and non-imidazole-based compounds. Preliminary studies have focused on the development of the imidazole type compounds which are structurally similar to histamine but, due to some undesirable features, they failed to enter the pharmaceutical market [130]. Hence, researchers turned their attention to imidazole ring bioisosteres in an attempt to develop non-imidazole type compounds such as piperidine, piperazine and pyrimidine. This approach resulted in e.g., pitolisant. The ligands with diverse scaffolds have been docked to $\mathrm{H}_{3} \mathrm{R}$ models, including amino acetylenic benzophenone derivatives [59], flavones [79], isoflavones [90], tert-amylphenoxyalkyl (homo)piperidine derivatives [88], piperazine derivatives including tert-butyl/tert-pentylphenoxyalkyl, acetyl/propionyl phenoxyalkyl, 4-pyridyl, and (dihydro)benzofuranyl $[29,67,86,89]$, tetrahydroquinazolinamines [62] or pramepexole carbamodithiolate metal complexes [131]. A series of flavone derivatives was designed and docked to $\mathrm{H}_{3} \mathrm{R}$ model. The flavones were observed to form a salt bridge with $\mathrm{E}^{5.46}$, $\pi$-anion bond with $\mathrm{D}^{3.32}$, H-bond with $\mathrm{Y}^{6.51}$, and the hydrophobic interactions with $\mathrm{Y}^{3.33}, \mathrm{C}^{3.36}$, $\mathrm{A}^{5.42}, \mathrm{~W}^{6.48}, \mathrm{Y}^{6.51}$, and $\mathrm{L}^{7.42}[79]$ while isoflavones formed a salt bridge with $\mathrm{E}^{5.42}$ and $\pi-\pi$ interactions with $\mathrm{Y}^{3.33}$ and $\mathrm{F}^{5.38}$ [90]. In another study, the tert-amylphenoxyalkyl 
(homo)piperidine derivatives were docked to $\mathrm{H}_{3} \mathrm{R}$ model built on $\mathrm{M}_{3}$ muscarinic acetylcholine receptor in GPCRM structure modeling server [132]. It was observed while docking these derivatives that a salt bridge was formed with residue $E^{5.46}$, and $\pi-\pi$ stacking with $\mathrm{Y}^{3.33}, \mathrm{~F}^{5.39}$ and/or $\mathrm{Y} 189^{\mathrm{ECL} 2}$ [88]. In the case of a novel series of piperazine derivatives (tert-butyl/tert-pentylphenoxyalkyl, acetyl/propionyl phenoxyalkyl and 4-pyridyl), the ligands were observed to form $\mathrm{H}$-bond/salt bridge with $\mathrm{E}^{5.46}$, and $\mathrm{H}$-bond with $\mathrm{Y}^{6.51}$ while forming $\pi-\pi$ interactions with $\mathrm{W}^{6.48}$ and $\mathrm{F}^{5.47}$. Additionally, the ligands were found to be stabilized through $\pi-\pi$ stacking with at least one of the following residues: $Y^{3.33}, Y^{7.35}$ and F193 ${ }^{\mathrm{ECL} 2}$ [67]. An additional hydrogen bond with residue $\mathrm{R}^{6.58}$ could have a positive influence on $\mathrm{H}_{3} \mathrm{R}$ affinity [89]. Ligands with 4-pyridyl piperazine scaffold were found to be $\mathrm{H}_{3} \mathrm{R}$ selective antagonists as compared to $\mathrm{H}_{3} \mathrm{R}, \mathrm{D}_{2} \mathrm{R}, \mathrm{M}_{1} \mathrm{R}$ and $\alpha_{1}$-adrenergic receptors [61]. Dihydrobenzofuranyl-piperazines analogs with 5-phenyl and allylpiperazine modifications were recently found to be the potent $\mathrm{hH}_{3} \mathrm{R}$ antagonists with nanomolar affinity [86].

Wagner et al. [81] have evaluated a series of 4-(3-aminoazetidin-1-yl)pyrimidin-2amines as high affinity $\mathrm{H}_{3} \mathrm{R}$ partial agonists obtained from an in-house screening campaign (Compound 11). All these ligands along with histamine, when docked using PLANTS and after MD simulations as $\mathrm{H}_{3} \mathrm{R}$ complex, have maintained stable crucial interactions with $\mathrm{D}^{3.32}, \mathrm{E}^{5.46}$ and $\mathrm{Y}^{6.51}$ [81]. Two bidirectional GPCR photoswitchable antagonists with substituted azobenzene scaffold (VUF14738 and VUF14862 (Compound 9 in Figure 2) were developed by Hauwert et al. They possessed 10-100 fold higher $\mathrm{H}_{3} \mathrm{R}$ selectivity over $\mathrm{H}_{1} \mathrm{R}$ and no measurable $\mathrm{H}_{4} \mathrm{R}$ affinity [60]. Recently, $\mathrm{Z} 3303614736$ have been found to be new strong inverse agonist of $\mathrm{H}_{3} \mathrm{R}$ that inactivates the receptor in a nanomolar concentration range. It was identified by using the intramolecular $\mathrm{H}_{3} \mathrm{R}$ biosensor based on bioluminescence resonance energy transfer (BRET) that is sensitive to the conformational dynamics of $\mathrm{H}_{3} \mathrm{R}$ and can be used to screen for the receptor agonists and inverse agonists in a live cell [133]. Nonimidazole antagonists/inverse agonists of $\mathrm{H}_{3} \mathrm{R}$ with nanomolar activity as anticonvulsant drugs were obtained by Song et al. [134] by linking the $\mathrm{H}_{3} \mathrm{R}$ pharmacophore (aliphatic amine with propyloxy chain) with the 1,2,4-triazole moiety. Docking studies indicated that these ligands were bound to $\mathrm{Y}^{3.33}$ and $\mathrm{E}^{5.46}$, and additionally to $\mathrm{R}^{6.58}, \mathrm{~F} 193^{\mathrm{ECL} 2}$ and $\mathrm{M}^{6.55}$ [134].

\subsubsection{Multi-Target $\mathrm{H}_{3} \mathrm{R}$ Ligands}

Recently, the multi-target-directed ligands of histamine receptors gained a lot of attention $[45,57,68,78,94,95]$ that led to development of multi-targeted ligands of $\mathrm{H}_{3} \mathrm{R}$, serotonin receptors, as well as acetylcholinesterases (AChE and $\mathrm{BuChE}$ ), for potential treatment of neurodegenerative diseases such as Alzheimer's disease. Jonczyk et al. [68] identified multi-targeted piperazine derivatives to be blockers of $\mathrm{AChE}$ and $\mathrm{BuChE}$ as well as of $\mathrm{hH}_{3} \mathrm{R}$. The ligands were bound to $\mathrm{E}^{5.46}$, as this was suggested to be a crucial interaction for $\mathrm{H}_{3} \mathrm{R}$ antagonistic activity, while the other interactions were with residues $\mathrm{F} 163^{\mathrm{ECL} 2}, \mathrm{Y}^{3.33}$ and $Y^{6.51}$ [68]. Lepailleur et al. [49] performed ligand-based pharmacophore-guided virtual screening of CERMN chemical compound library (17,194 compounds) using six active $\mathrm{H}_{3} \mathrm{R}$ ligands with the purpose of designing dual targeting $\mathrm{H}_{3} \mathrm{R} / 5-\mathrm{HT}_{4} \mathrm{R}$ ligands. Ligand docking was performed using the Schrodinger Glide Induced Fit procedure. The best ligands appeared to be benzo[ $h][1,6]$ naphthyridine derivatives. The pharmacophoric features correlated well with the interacting residues: protonated amine (basic center) formed a salt bridge with $\mathrm{D}^{3.32}$, the aromatic system formed a $\pi-\pi$ interaction with indole ring of $\mathrm{W}^{6.48}$, the hydrophobic part was surrounded by residues $\mathrm{L}^{3.29}, \mathrm{~W}^{3.28}$ and $\mathrm{F}^{7.39}$, and the $\mathrm{NH}$ of the tricyclic system served as a H-bond donor bound to the side chain of $\mathrm{E}^{5.46}$. The ligands including the most potent Compound $\mathbf{6}$ in Figure 2 possessed two positively ionizable groups (imidazole, alkylamine) that were sometimes supposed to interact with residues $\mathrm{D}^{2.50}$ or with E175 ${ }^{\mathrm{ECL} 2}$ and E191 ${ }^{\mathrm{ECL} 2}$ [49]. Darras et al. [57] performed computational studies followed by synthesis and biological evaluation for synergistic effects of tri- and tetracyclic nitrogen bridgehead compounds reported as dual acting $\mathrm{hH}_{3} \mathrm{R}$ antagonists and AChE inhibitors. The tricyclic partial structure of the most potent and selective $\mathrm{H}_{3} \mathrm{R}$ 
compound in this study remained stably bound in a pocket formed by residues $\mathrm{L}^{3.29}, \mathrm{Y}^{3.33}$, $\mathrm{C}^{3.36}, \mathrm{~W}^{6.48}, \mathrm{Y}^{6.51}, \mathrm{M}^{6.55}$, and $\mathrm{F} 193^{\mathrm{ECL} 2}$. Two stable ionic interactions between $\mathrm{D}^{3.32}$ and a positively charged piperidine moiety of compounds, as well as between $\mathrm{E}^{5.46}$ and a positively charged amidine moiety were observed during entire MD simulation. Also, an aromatic interaction was observed between an aromatic moiety of a docked Compound $\mathbf{1 0}$ with $\mathrm{Y}^{3.33}$ and F193 ${ }^{\mathrm{ECL} 2}$ [57].

A series of twenty new chlorophenoxyalkylamine derivatives was reported as dual acting $\mathrm{hH}_{3} \mathrm{R}$ antagonists and $\mathrm{AChE} / \mathrm{BuChE}$ inhibitors [94,95]. The $\mathrm{hH}_{3} \mathrm{R}$ model was developed using GPCRM webserver and validated using pitolisant as a reference $\mathrm{H}_{3} \mathrm{R}$ ligand. All these compounds were docked to target proteins using Schrodinger Glide software. It was observed that irrespective of alkyl chain length, chloro substituted phenyl rings were in close contact with ECL2 residues (W174, L177, A190, E191, Y194 and W196) [94,95]. The multitarget-directed ligands with $\mathrm{H}_{3} \mathrm{R}$ antagonistic activity coupled with the ability to inhibit acetyl/butyrylcholinesterases and monoamine oxidases A/B, potentially suitable for the treatment of Alzheimer's or Parkinson's disease, were studied by Bautista-Aguilera et al. [78]. All the studied compounds revealed an interesting neuroprotection profile against oligomycin $\mathrm{A}$, okadaic acid (as a model of the hyperphosphorylation of tau), and $\beta$ amyloid peptide $A \beta_{25-35}$. Of all ligands the non-imidazole ligand, contilisant, had the best properties. Recently, 26 non-imidazole histamine $\mathrm{H}_{3} \mathrm{R}$ ligands and 23 xanthone derivatives, rationally designed using a pharmacophore model for $\mathrm{H}_{3} \mathrm{R}$ antagonists/inverse agonists, have been confirmed as potential anti-Alzheimer agents by docking to $\mathrm{H}_{3} \mathrm{R}$ and acetyland butyrylcholinesterases. The most promising derivatives combined the flavone moiety via a six carbon atom linker with a heterocyclic moiety, such as azepane, piperidine or 3-methylpiperidine [121,122].

\subsection{Computational Studies on $\mathrm{H}_{4} \mathrm{R}$ and Its Ligands}

\subsubsection{Homology Modeling and Structural Aspects of $\mathrm{H}_{4} \mathrm{R}$}

$\mathrm{H}_{4} \mathrm{R}$ (UniProt id:Q9H3N8, 390 amino acids) possess $40 \%$ identity in TM region to $\mathrm{H}_{1} \mathrm{R}$ which led many researchers to generate $\mathrm{H}_{4} \mathrm{R}$ homology models using $\mathrm{H}_{1} \mathrm{R}$ crystal structure as a template. However, there are substantial differences in their binding sites as the residues $\mathrm{K}^{5.39}, \mathrm{~N}^{5.46}$ and $\mathrm{G}^{7.42}$ in $\mathrm{H}_{1} \mathrm{R}$ are equivalent to $\mathrm{L}^{5.39}, \mathrm{E}^{5.46}$ and $\mathrm{Q}^{7.42}$ in $\mathrm{H}_{4} \mathrm{R}$. The large sequence similarity (37\%) and structural similarity $(58 \%)$ in the binding site between $\mathrm{H}_{3} \mathrm{R}$ and $\mathrm{H}_{4} \mathrm{R}$, confirmed by mutagenesis studies, emphasized a crucial role of identical residues: $\mathrm{D}^{3.32}, \mathrm{E}^{5.46}, \mathrm{Y}^{3.33}, \mathrm{~W}^{6.48}$ and $\mathrm{Y}^{6.51}$ in ligand binding that results in similar ligand poses in the binding site and can explain the mechanism of dual $\mathrm{H}_{3} \mathrm{R} / \mathrm{H}_{4} \mathrm{R}$ antagonism [36,57]. Importance of specific residues for ligand binding was confirmed by mutations: $\mathrm{E}^{5.46} \mathrm{Q}$ had decreased the affinity of clobenpropit and its derivatives toward $\mathrm{H}_{3} \mathrm{R}$ and $\mathrm{H}_{4} \mathrm{R}$ while mutations $\mathrm{L}^{5.39} \mathrm{~V}$ and $\mathrm{E}^{5.46} \mathrm{Q}$ decreased the affinity of ligands against $\mathrm{H}_{4} \mathrm{R}$. The mutagenesis also revealed importance of $\mathrm{N}^{4.57}, \mathrm{~L}^{5.39}$ and $\mathrm{E}^{5.46}$ for antagonist binding while featuring $\mathrm{H}$-bonds/electrostatic interactions with two negatively charged residues $\mathrm{D}^{3.32}$ and $\mathrm{E}^{5.46}$ to be important for receptor activation $[27,53,72,135]$. Combined mutagenesis and protein-ligand modeling studies performed to explain $\mathrm{H}_{3} \mathrm{R}$ and $\mathrm{H}_{4} \mathrm{R}$ selectivity indicate that the residue at position $4.57\left(\mathrm{Y}^{4.57}\right.$ in $\mathrm{H}_{3} \mathrm{R}$ and $\mathrm{N}^{4.57}$ in $\left.\mathrm{H}_{4} \mathrm{R}\right)$ is directed toward the ligand binding pocket. This suggests that the TM4 of $\mathrm{H}_{3} \mathrm{R}$ and $\mathrm{H}_{4} \mathrm{R}$ remains undistorted making the constriction unique for the $\mathrm{H}_{1} \mathrm{R}$ subtype [136]. The pharmacological profile of $\mathrm{H}_{4} \mathrm{R}$ ligands was recently reviewed by our group [137].

The residues in ECL2 (the largest and the most structurally diverse extracellular loop of class A GPCRs) are also important for binding of ligands to all monoaminergic GPCRs as revealed by site-directed mutagenesis experiments. ECL2 also plays an important role as a stabilizer of the inactive state of the receptor [138]. Mutagenesis of two ECL2 phenylalanine residues (FF motif) in $\mathrm{hH}_{4} \mathrm{R}$ resulted in reduced constitutive and ligand-induced receptor activation, which points to a significant involvement of this motif in receptor activation $[80,82,96]$. Mutations of these residues can change the pharmacological properties of ligands: thioperamide is a partial inverse agonist at $\mathrm{hH}_{4} \mathrm{R} \mathrm{F16}{ }^{\mathrm{ECL} 2} \mathrm{~V}$, which is a mutant 
with reduced constitutive activity, and a neutral antagonist at $\mathrm{hH}_{4} \mathrm{R} \mathrm{F168}{ }^{\mathrm{ECL} 2} \mathrm{~A}$ a mutant devoid of constitutive activity. It was concluded that $\mathrm{F} 168^{\mathrm{ECL} 2}$ is a key determinant of $\mathrm{H}_{4} \mathrm{R}$ constitutive activity, ligand binding and potency as compared to F169 ${ }^{\mathrm{ECL} 2}$. These studies reveal a crucial role of the FF motif, F168 ${ }^{\mathrm{ECL} 2}$ and F169 ${ }^{\mathrm{ECL} 2}$, in both ligand-receptor interactions and constitutive activity (interconversion between active and inactive conformation) of the wild-type $\mathrm{hH}_{4} \mathrm{R}$ [82].

\subsubsection{Ligands Targeting $\mathrm{H}_{4} \mathrm{R}$ and Their Interactions}

Kiss et al. identified novel histamine $\mathrm{H}_{4} \mathrm{R}$ ligands through the ensemble docking based on homology model conformers obtained from MD simulations. Such representative $\mathrm{hH}_{4} \mathrm{R}$ conformers were found to be more suitable for the identification of $\mathrm{H}_{4} \mathrm{R}$ antagonists than the initial homology models [25]. It was also found that X-ray and homology model structures may be complementary, or at least able to sample different protein conformations leading to non-overlapping hits and can provide important starting points for fragment-based lead discovery for other GPCRs [6]. Labeeuw et al. [22] discovered a potent antagonist (Compound 12) among 2-benzothiazolylphenylmethyl ether analogues. It was identified in a virtual screening of a corporate compound collection based on $\mathrm{H}_{4} \mathrm{R}$ model, followed by hit optimization with the purpose of designing potent and selective $\mathrm{H}_{4} \mathrm{R}$ antagonists. As for the binding mode the imidazole ring of the scaffold was suggested to form a salt bridge with $\mathrm{D}^{3.32}$, the oxygen of the linker a H-bond with the phenol moiety of $\mathrm{Y}^{3.33}$, and the nitrogen atom of the benzothiazolyl group a H-bond with $\mathrm{Y}^{6.51}$. Istyastono et al. [53] have explored complementary retrospective and prospective SBVS using $\beta_{2} \mathrm{R}$-based and $\mathrm{H}_{1} \mathrm{R}$ based $\mathrm{H}_{4} \mathrm{R}$ homology models with a IFP scoring on fragment-like ligands, which allowed identification of $\mathrm{H}_{4} \mathrm{R}$ ligands (including Compound 14) that were not spotted during LBVS runs. Although the authors observed higher enrichments in a model based on $\beta_{2} A R$ as compared to a model based on $\mathrm{H}_{1} \mathrm{R}$, an exchange of templates did not significantly affect SBVS accuracy. The TM binding pocket was very similar in both $\mathrm{H}_{4} \mathrm{R}$ models, based on $\beta_{2} \mathrm{AR}$ and $\mathrm{H}_{1} \mathrm{R}$, with little differences in ECL2. In the $\beta_{2} \mathrm{AR}$-based $\mathrm{H}_{4} \mathrm{R}$ model, the chlorine atom of JNJ7777120 was accommodated between $\mathrm{L}^{5.39}, \mathrm{~T}^{6.55}$ and F168 ${ }^{\mathrm{ECL} 2}$, while in the $\mathrm{H}_{1} \mathrm{R}$-based model it was located close to residues $\mathrm{L}^{5.39}, \mathrm{~T}^{5.42}$ and F168 ${ }^{\text {ECL2 }}$ [53]. Details of the orthosteric binding site of homology model of $\mathrm{hH}_{4} \mathrm{R}$ are shown in Figure 7.

With the constantly growing number of $\mathrm{H}_{4} \mathrm{R}$ ligands, the applicability of a large group of azine derivatives has been increased. A promising series of novel selective $\mathrm{H}_{4} \mathrm{R}$ antagonists, such as 2-amino-4-methylpiperazine-1,3,5-triazines, was designed and synthesized by different research groups by introducing variously substituted arylethenyl moieties [24,92,139]. Lazewska et al. [24] docked these molecules on the validated $\mathrm{H}_{4} \mathrm{R}$ homology model built using a template of $\mathrm{H}_{1} \mathrm{R}$. All compounds with triazine core including Compound 15 were found to interact with $\mathrm{D}^{3.32}$ in two possible ligand orientations in the binding pocket of $\mathrm{H}_{4} \mathrm{R}$. The protonated nitrogen of the most active ligands formed a weak interaction with $E^{5.46}$. The triazine core of ligands was found to interact with $\mathrm{Y}^{3.33}$ and also with $\mathrm{T}^{5.42}$ and $\mathrm{Y}^{6.51}$. Halogen atoms para substituted to the benzene ring were found to fit in the hydrophobic pocket formed by residues $\mathrm{V}^{2.53}, \mathrm{I}^{2.58}$ and $\mathrm{W}^{3.28}$. Among them, 4-(cyclohexylmethyl)-6-(4-methylpiperazin-1-yl)-1,3,5-triazin-2-amine exhibited the highest $\mathrm{hH}_{4} \mathrm{R}$ affinity with $\mathrm{K}_{\mathrm{i}}$ of $160 \mathrm{nM}$ and showed anti-inflammatory properties in the carrageenan-induced edema test during preliminary studies in mice [24]. Mogilski et al. [139] identified two promising structures with chlorine and bromine atoms at paraposition in the aromatic ring as potential anti-inflammatory agents more potent than the reference compound JNJ7777120. They were shown to inhibit the inflammatory response in two different in vivo models of inflammation, the carrageenan-induced model and zymosan-induced peritonitis [139]. 


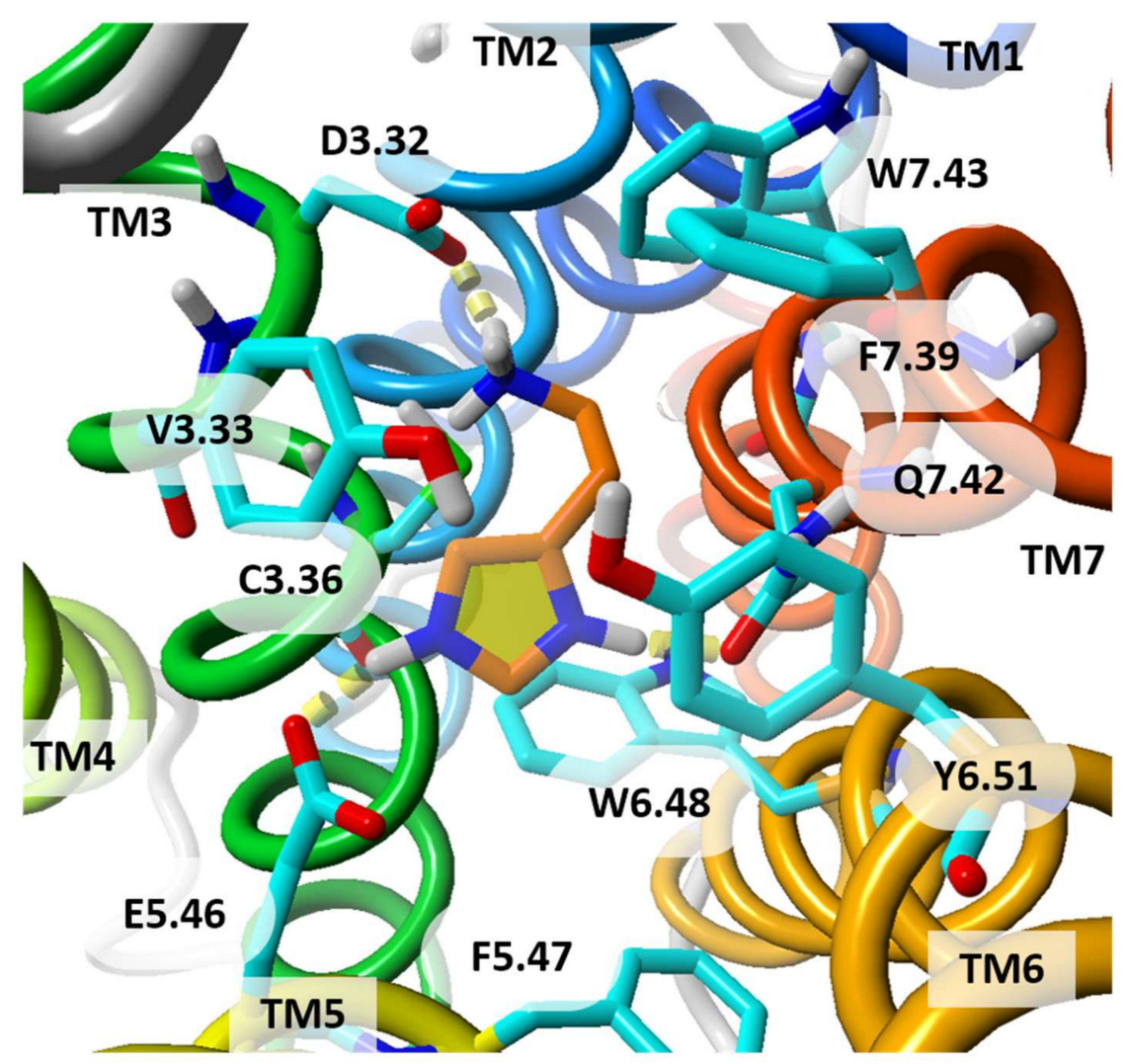

Figure 7. Histamine molecule docked to the homology model of $\mathrm{hH}_{4} \mathrm{R}$. The histamine is doubly positively charged. The amine moiety of histamine is bound to $\mathrm{D}^{3.32}$ whereas the imidazole ring is bound to $\mathrm{E}^{5.46}$ and $\mathrm{Q}^{7.42}$. The histamine hydrophobic linker is exposed toward hydrophobic residues $\mathrm{F}^{7.39}$ and inversely rotated $\mathrm{W}^{7.43}$. The residue numbers are shown in Ballesteros-Weinstein numbering scheme. Histamine is shown with its carbon atoms colored in orange. View from extracellular side. TM helices are colored from blue (TM1) to red (TM7).

Levoin et al. [23] discovered novel scaffolds using virtual screening on the Prestwick library in a two-step process: (i) using a "scout screening" methodology for a small size chemical library with the very diverse structures, and (ii) by using the refined 3D model of $\mathrm{H}_{4} \mathrm{R}$ to conduct a widened virtual screening. This two-step strategy proved to be successful, both in terms of structural diversity and hit rate (23\%). Moreover, the hits had the high affinities for $\mathrm{H}_{4} \mathrm{R}$, with the most potent ligands in the nanomolar affinity range [23]. Ko et al. discovered a novel series of pyrido[2,3-e]tetrazolo[1,5-a]pyrazine analogues as orally available potent and highly selective $\mathrm{H}_{4} \mathrm{R}$ antagonists with strong antipruritus and antiinflammatory activity [26]. The authors used a pharmacophore-based virtual screening on ZINC12 database incorporating iterative clustering with Tanimoto similarity (similarity coefficient $\geq 0.9$ ). This approach resulted in eight pharmacophores with four features. A $\mathrm{H}_{4} \mathrm{R}$ model was constructed using the $\mathrm{H}_{1} \mathrm{R}$ template and refined using MD simulations. The basic amine of $N$-methylpiperazine of a lead formed a crucial ionic interaction with $\mathrm{D}^{3.32}$ while the main scaffold formed the $\pi-\pi$ interactions with residues $\mathrm{Y}^{3.33}, \mathrm{~W}^{6.48}, \mathrm{Y}^{6.51}$, and $\mathrm{F} 168^{\mathrm{ECL} 2}$.

Geyer et al. [63] studied constrained analogues of the imidazolylbutylcyanoguanidines substituted by cyclopentane-1,3-diyl moiety and identified the most active enantiomer (Compound 13). The imidazole moiety of enantiomers of this compound was found to be embedded in a slightly different orientation in the binding pocket of $\mathrm{H}_{4} \mathrm{R}$, which resulted in an order of magnitude higher affinity of Compound $\mathbf{1 3}$ to $\mathrm{H}_{4} \mathrm{R}$, in comparison to other enantiomers, and in two orders of magnitude higher selectivity compared to $\mathrm{H}_{3} \mathrm{R}$. Such differences originated from different interactions at residues 6.52 and 7.42 in both receptors. The imidazole ring and the cyanoguanidine group were in contact with these residues in 
$\mathrm{H}_{4} \mathrm{R}\left(\mathrm{S}^{6.52}\right.$ and $\left.\mathrm{Q}^{7.42}\right)$ but not in $\mathrm{H}_{3} \mathrm{R}\left(\mathrm{T}^{6.52}\right.$ and $\left.\mathrm{L}^{7.42}\right)$ [63]. Hammer et al. [31] studied the substituted 2,4-diaminopyrimidines as dual ligands of $\mathrm{H}_{1} \mathrm{R}$ and $\mathrm{H}_{4} \mathrm{R}$ and their docking poses were stabilized in MD simulations. In this study, the positively charged piperazine moiety was observed to interact with $\mathrm{D}^{3.32}$ while $\mathrm{Y}^{6.51}$ formed a stable interaction with $\mathrm{E}^{5.46}$ The authors speculated that the subtype differences between $\mathrm{H}_{1} \mathrm{R}$ and $\mathrm{H}_{4} \mathrm{R}$, hampering the identification of dual, high affinity $\mathrm{H}_{1} \mathrm{R} / \mathrm{H}_{4} \mathrm{R}$ ligands, might be due to the residue at position 3.40 ( $\mathrm{I}^{3.40}$ in $\mathrm{H}_{1} \mathrm{R}$ and $\mathrm{V}^{3.40}$ in $\left.\mathrm{H}_{4} \mathrm{R}\right)$ [31]. Additionally, the residue at position 7.42 ( $\left(\mathrm{L}^{7.42}\right.$ in $\mathrm{H}_{3} \mathrm{R}$ and $\mathrm{Q}^{7.42}$ in $\mathrm{H}_{4} \mathrm{R}$ ) might be important for $\mathrm{H}_{3} \mathrm{R} / \mathrm{H}_{4} \mathrm{R}$ selectivity as it was shown in a recent study by Correa et al. for benzofuranyl-piperazine with a carbonyl group in a linker between these moieties [86].

\title{
3. Conclusions
}

The ligands of histamine receptors are increasingly used in treatment of various pathological conditions including allergic diseases, inflammation, neurological disorders, and possibly also obesity. Three histamine receptors, $\mathrm{H}_{1} \mathrm{R}-\mathrm{H}_{3} \mathrm{R}$, have been well established while $\mathrm{H}_{4} \mathrm{R}$ is a novel, attractive drug target for allergic and inflammatory disorders. HR antagonists proved to be efficacious and relatively safe in animal models and several clinical trials are currently conducted or have been recently completed. Extensive drug design and medicinal chemistry attempts exploring structure-activity relationships led to the development of numerous novel selective HR ligands. Molecular docking proved to be a valuable technique to analyze ligand recognition and together with virtual screening has led to important drug discoveries in the field of histamine receptors. However, more crystal structures of all histamine receptors, both in inactive and active states, are needed to profoundly understand the structural details of their binding sites and the resulting signaling in order to design specific ligands with desired pharmacological profiles.

Author Contributions: Conceptualization, P.M. (Pakhuri Mehta) and S.F.; writing-original draft preparation, P.M. (Pakhuri Mehta); writing-review and editing, P.M. (Pakhuri Mehta), P.M. (Przemysław Miszta) and S.F.; visualization, P.M. (Pakhuri Mehta), P.M. (Przemysław Miszta) and S.F; supervision, S.F.; funding acquisition, S.F. All authors have read and agreed to the published version of the manuscript.

Funding: This research was funded by National Science Centre, Poland, grant OPUS 2017/25/B/NZ7/ 02788 for S.F.

Institutional Review Board Statement: Not applicable.

Informed Consent Statement: Not applicable.

Data Availability Statement: Not applicable.

Conflicts of Interest: The authors declare no conflict of interest. The funders had no role in the design of the study; in the collection, analyses, or interpretation of data; in the writing of the manuscript, or in the decision to publish the results.

\begin{abstract}
Abbreviations
GPCRs_-G Protein-Coupled Receptors; HRs-Histamine Receptors; TM-Transmembrane; ECLExtracellular Loop; SBVS—Structure-Based Virtual Screening; LBVS_Ligand-Based Virtual Screening; IFP-Interaction Fingerprint; SAR—Structure-Activity Relationship; MD—Molecular Dynamics.
\end{abstract}

\section{References}

1. Buchan, N.S.; Rajpal, D.K.; Webster, Y.; Alatorre, C.; Gudivada, R.C.; Zheng, C.; Sanseau, P.; Koehler, J. The role of translational bioinformatics in drug discovery. Drug Discov. Today 2011, 16, 426-434. [CrossRef] [PubMed]

2. Kolb, P.; Ferreira, R.S.; Irwin, J.J.; Shoichet, B.K. Docking and chemoinformatic screens for new ligands and targets. Curr. Opin. Biotechnol. 2009, 20, 429-436. [CrossRef] [PubMed]

3. Kumar, A.; Zhang, K.Y. Hierarchical virtual screening approaches in small molecule drug discovery. Methods $2015,71,26-37$. [CrossRef] 
4. Tuccinardi, T. Docking-based virtual screening: Recent developments. Comb. Chem. High Throughput Screen. 2009, $12,303-314$. [CrossRef]

5. Lenselink, E.B.; Jespers, W.; van Vlijmen, H.W.; IJzerman,, A.P.; van Westen, G.J. Interacting with GPCRs: Using Interaction Fingerprints for Virtual Screening. J. Chem. Inf. Model. 2016, 56, 2053-2060. [CrossRef]

6. Vass, M.; Schmidt, E.; Horti, F.; Keseru, G.M. Virtual fragment screening on GPCRs: A case study on dopamine D3 and histamine H4 receptors. Eur. J. Med. Chem. 2014, 77, 38-46. [CrossRef]

7. Tian, S.; Wang, X.; Li, L.; Zhang, X.; Li, Y.; Zhu, F.; Huo, T.; Zhen, X. Discovery of Novel and Selective Adenosine A2A Receptor Antagonists for Treating Parkinson's Disease through Comparative Structure-based Virtual Screening. J. Chem. Inf. Model. 2017, 57, 1474-1487. [CrossRef]

8. Szollosi, E.; Bobok, A.; Kiss, L.; Vass, M.; Kurko, D.; Kolok, S.; Visegrady, A.; Gyorgy, M.; Keseru, G.M. Cell-based and virtual fragment screening for adrenergic $\alpha 2 C$ receptor agonists. Bioorg. Med. Chem. 2015, 23, 3991-3999. [CrossRef]

9. Kooistra, A.J.; Vischer, H.F.; McNaught-Flores, D.; Leurs, R.; de Esch, I.J.; de Graaf, C. Function-specific virtual screening for GPCR ligands using a combined scoring method. Sci. Rep. 2016, 6, 28288. [CrossRef] [PubMed]

10. Shonberg, J.; Kling, R.C.; Gmeiner, P.; Lober, S. GPCR crystal structures: Medicinal chemistry in the pocket. Bioorg. Med. Chem. 2015, 23, 3880-3906. [CrossRef]

11. Zaid, H.; Raiyn, J.; Osman, M.; Falah, M.; Srouji, S.; Rayan, A. In silico modeling techniques for predicting the tertiary structure of human H4 receptor. Front. Biosci. (Landmark Ed.) 2016, 21, 597-619. [CrossRef]

12. Pappalardo, M.; Shachaf, N.; Basile, L.; Milardi, D.; Zeidan, M.; Raiyn, J.; Guccione, S.; Rayan, A. Sequential application of ligand and structure based modeling approaches to index chemicals for their hH4R antagonism. PLoS ONE 2014, 9, e109340. [CrossRef]

13. Ehling, S.; Rossbach, K.; Dunston, S.M.; Stark, H.; Baumer, W. Allergic inflammation is augmented via histamine H4 receptor activation: The role of natural killer cells in vitro and in vivo. J. Dermatol. Sci. 2016, 83, 106-115. [CrossRef]

14. Mommert, S.; Kleiner, S.; Gehring, M.; Eiz-Vesper, B.; Stark, H.; Gutzmer, R.; Werfel, T.; Raap, U. Human basophil chemotaxis and activation are regulated via the histamine H4 receptor. Allergy 2016, 71, 1264-1273. [CrossRef] [PubMed]

15. Nicoud, M.B.; Formoso, K.; Medina, V.A. Pathophysiological Role of Histamine H4 Receptor in Cancer: Therapeutic Implications. Front. Pharmacol. 2019, 10, 556. [CrossRef]

16. Sanna, M.D.; Stark, H.; Lucarini, L.; Ghelardini, C.; Masini, E.; Galeotti, N. Histamine H4 receptor activation alleviates neuropathic pain through differential regulation of ERK, JNK, and P38 MAPK phosphorylation. Pain 2015, 156, 2492-2504. [CrossRef] [PubMed]

17. de Esch, I.J.; Thurmond, R.L.; Jongejan, A.; Leurs, R. The histamine H4 receptor as a new therapeutic target for inflammation. Trends Pharmacol. Sci. 2005, 26, 462-469. [CrossRef]

18. Salem, A.; Almahmoudi, R.; Listyarifah, D.; Siponen, M.; Maaninka, K.; Al-Samadi, A.; Salo, T.; Eklund, K.K. Histamine H4 receptor signalling in tongue cancer and its potential role in oral carcinogenesis-A short report. Cell. Oncol. 2017, 40, 621-630. [CrossRef]

19. Ahmad, S.F.; Zoheir, K.M.; Abdel-Hamied, H.E.; Alrashidi, I.; Attia, S.M.; Bakheet, S.A.; Ashour, A.E.; Abd-Allah, A.R. Role of a histamine 4 receptor as an anti-inflammatory target in carrageenan-induced pleurisy in mice. Immunology 2014, 142, 374-383. [CrossRef] [PubMed]

20. Kaneko, H.; Ye, F.; Ijima, R.; Kachi, S.; Kato, S.; Nagaya, M.; Higuchi, A.; Terasaki, H. Histamine H4 receptor as a new therapeutic target for choroidal neovascularization in age-related macular degeneration. Br. J. Pharmacol. 2014, 171, 3754-3763. [CrossRef]

21. Czerner, C.P.; Klos, A.; Seifert, R.; Neumann, D. Histamine induces chemotaxis and phagocytosis in murine bone marrow-derived macrophages and RAW 264.7 macrophage-like cells via histamine H4-receptor. Inflamm. Res. 2014, 63, 239-247. [CrossRef]

22. Labeeuw, O.; Levoin, N.; Billot, X.; Danvy, D.; Calmels, T.; Krief, S.; Ligneau, X.; Berrebi-Bertrand, I.; Robert, P.; Lecomte, J.M.; et al. Synthesis and evaluation of a 2-benzothiazolylphenylmethyl ether class of histamine H4 receptor antagonists. Bioorg. Med. Chem. Lett. 2016, 26, 5263-5266. [CrossRef]

23. Levoin, N.; Labeeuw, O.; Billot, X.; Calmels, T.; Danvy, D.; Krief, S.; Berrebi-Bertrand, I.; Lecomte, J.M.; Schwartz, J.C.; Capet, M. Discovery of nanomolar ligands with novel scaffolds for the histamine H4 receptor by virtual screening. Eur. J. Med. Chem. 2017, 125, 565-572. [CrossRef] [PubMed]

24. Lazewska, D.; Mogilski, S.; Hagenow, S.; Kuder, K.; Gluch-Lutwin, M.; Siwek, A.; Wiecek, M.; Kaleta, M.; Seibel, U.; Buschauer, A.; et al. Alkyl derivatives of 1,3,5-triazine as histamine H4 receptor ligands. Bioorg. Med. Chem. 2019, 27, 1254-1262. [CrossRef] [PubMed]

25. Kiss, R.; Jojart, B.; Schmidt, E.; Kiss, B.; Keseru, G.M. Identification of Novel Histamine H4 Ligands by Virtual Screening on Molecular Dynamics Ensembles. Mol. Inform. 2014, 33, 264-268. [CrossRef] [PubMed]

26. Ko, K.; Kim, H.J.; Ho, P.S.; Lee, S.O.; Lee, J.E.; Min, C.R.; Kim, Y.C.; Yoon, J.H.; Park, E.J.; Kwon, Y.J.; et al. Discovery of a Novel Highly Selective Histamine H4 Receptor Antagonist for the Treatment of Atopic Dermatitis. J. Med. Chem. 2018, 61, $2949-2961$. [CrossRef]

27. Schultes, S.; Kooistra, A.J.; Vischer, H.F.; Nijmeijer, S.; Haaksma, E.E.J.; Leurs, R.; de Esch, I.J.P.; de Graaf, C. Combinatorial Consensus Scoring for Ligand-Based Virtual Fragment Screening: A Comparative Case Study for Serotonin 5-HT3A, Histamine H1, and Histamine H4 Receptors. J. Chem. Inf. Model. 2015, 55, 1030-1044. [CrossRef]

28. Lazewska, D.; Kuder, K.; Kononowicz, K. Monocyclic and Fused Azines and Azoles as Histamine H4 Receptor Ligands. Curr. Med. Chem. 2016, 23, 1870-1925. [CrossRef] 
29. Correa, M.F.; Barbosa, A.J.R.; Teixeira, L.B.; Duarte, D.A.; Simoes, S.C.; Parreiras, E.S.L.T.; Balbino, A.M.; Landgraf, R.G.; Bouvier, M.; Costa-Neto, C.M.; et al. Pharmacological Characterization of 5-Substituted 1-[(2,3-dihydro-1-benzofuran-2yl)methyl]piperazines: Novel Antagonists for the Histamine H3 and H4 Receptors with Anti-inflammatory Potential. Front. Pharmacol. 2017, 8, 825. [CrossRef]

30. Watanabe, M.; Kobayashi, T.; Ito, Y.; Fukuda, H.; Yamada, S.; Arisawa, M.; Shuto, S. Design and synthesis of histamine H3/H4 receptor ligands with a cyclopropane scaffold. Bioorg. Med. Chem. Lett. 2018, 28, 3630-3633. [CrossRef] [PubMed]

31. Hammer, S.G.; Gobleder, S.; Naporra, F.; Wittmann, H.J.; Elz, S.; Heinrich, M.R.; Strasser, A. 2,4-Diaminopyrimidines as dual ligands at the histamine $\mathrm{H} 1$ and H4 receptor-H1/H4-receptor selectivity. Bioorg. Med. Chem. Lett. 2016, 26, 292-300. [CrossRef] [PubMed]

32. Shan, L.; Bao, A.M.; Swaab, D.F. The human histaminergic system in neuropsychiatric disorders. Trends Neurosci. 2015, 38, 167-177. [CrossRef] [PubMed]

33. Corrêa, M.F.; Fernandes, J.P.d.S. Histamine H4 receptor ligands: Future applications and state of art. Chem. Biol. Drug Des. 2015, 85, 461-480. [CrossRef]

34. Ballesteros, J.A.; Weinstein, H. Integrated methods for the construction of three-dimensional models and computational probing of structure-function relations in G protein-coupled receptors. In Methods in Neurosciences; Sealfon, S.C., Ed.; Academic Press: Cambridge, MA, USA, 1995; Volume 25, pp. 366-428.

35. Zhu, Y.; Michalovich, D.; Wu, H.-L.; Tan, K.B.; Dytko, G.M.; Mannan, I.J.; Boyce, R.; Alston, J.; Tierney, L.A.; Li, X.; et al. Cloning, Expression, and Pharmacological Characterization of a Novel Human Histamine Receptor. Mol. Pharmacol. 2001, 59, 434-441. [CrossRef]

36. Panula, P.; Chazot, P.L.; Cowart, M.; Gutzmer, R.; Leurs, R.; Liu, W.L.; Stark, H.; Thurmond, R.L.; Haas, H.L. International union of basic and clinical pharmacology. XCVIII. Histamine receptors. Pharmacol. Rev. 2015, 67, 601-655. [CrossRef] [PubMed]

37. Trzaskowski, B.; Latek, D.; Yuan, S.; Ghoshdastider, U.; Debinski, A.; Filipek, S. Action of molecular switches in GPCRsTheoretical and experimental studies. Curr. Med. Chem. 2012, 19, 1090-1109. [CrossRef]

38. Filipek, S. Molecular switches in GPCRs. Curr. Opin. Struct. Biol. 2019, 55, 114-120. [CrossRef] [PubMed]

39. Huang, E.S. Construction of a sequence motif characteristic of aminergic G protein-coupled receptors. Protein Sci. 2003, 12, 1360-1367. [CrossRef]

40. Palczewski, K.; Kumasaka, T.; Hori, T.; Behnke, C.A.; Motoshima, H.; Fox, B.A.; Le Trong, I.; Teller, D.C.; Okada, T.; Stenkamp, R.E.; et al. Crystal structure of rhodopsin: A G protein-coupled receptor. Science 2000, 289, 739-745. [CrossRef]

41. Shimamura, T.; Shiroishi, M.; Weyand, S.; Tsujimoto, H.; Winter, G.; Katritch, V.; Abagyan, R.; Cherezov, V.; Liu, W.; Han, G.W.; et al. Structure of the human histamine H1 receptor complex with doxepin. Nature 2011, 475, 65-70. [CrossRef]

42. Kooistra, A.J.; de Graaf, C.; Timmerman, H. The receptor concept in 3D: From hypothesis and metaphor to GPCR-ligand structures. Neurochem. Res. 2014, 39, 1850-1861. [CrossRef] [PubMed]

43. Brogi, S.; Tafi, A.; Desaubry, L.; Nebigil, C.G. Discovery of GPCR ligands for probing signal transduction pathways. Front. Pharmacol. 2014, 5, 255. [CrossRef] [PubMed]

44. Congreve, M.; Dias, J.M.; Marshall, F.H. Structure-based drug design for G protein-coupled receptors. Prog. Med. Chem. 2014, 53, 1-63. [CrossRef]

45. Kooistra, A.J.; Leurs, R.; de Esch, I.J.; de Graaf, C. From three-dimensional GPCR structure to rational ligand discovery. Adv. Exp. Med. Biol. 2014, 796, 129-157. [CrossRef] [PubMed]

46. Zobayer, N.; Hossain, A.B.M.A. In silico Characterization and Homology Modeling of Histamine Receptors. J. Biol. Sci. 2018, 18, 178-191. [CrossRef]

47. Pandy-Szekeres, G.; Munk, C.; Tsonkov, T.M.; Mordalski, S.; Harpsoe, K.; Hauser, A.S.; Bojarski, A.J.; Gloriam, D.E. GPCRdb in 2018: Adding GPCR structure models and ligands. Nucleic Acids Res. 2018, 46, D440-D446. [CrossRef]

48. Chovatiya, R.; Georrge, J.J. Identification of potential phytochemical inhibitors for the treatment of allergic asthma from the medicinal plants. In Proceedings of the 9th National Level Science Symposium, Rajkot, Gujarat, India, 14 February 2016; Volume 3, pp. 277-285.

49. Lepailleur, A.; Freret, T.; Lemaitre, S.; Boulouard, M.; Dauphin, F.; Hinschberger, A.; Dulin, F.; Lesnard, A.; Bureau, R.; Rault, S. Dual histamine H3R/serotonin 5-HT4R ligands with antiamnesic properties: Pharmacophore-based virtual screening and polypharmacology. J. Chem. Inf. Model. 2014, 54, 1773-1784. [CrossRef]

50. Frandsen, I.O.; Boesgaard, M.W.; Fidom, K.; Hauser, A.S.; Isberg, V.; Brauner-Osborne, H.; Wellendorph, P.; Gloriam, D.E. Identification of Histamine H3 Receptor Ligands Using a New Crystal Structure Fragment-based Method. Sci. Rep. 2017, 7, 4829. [CrossRef]

51. Ghamari, N.; Zarei, O.; Reiner, D.; Dastmalchi, S.; Stark, H.; Hamzeh-Mivehroud, M. Histamine H3 receptor ligands by hybrid virtual screening, docking, molecular dynamics simulations, and investigation of their biological effects. Chem. Biol. Drug Des. 2019, 93, 832-843. [CrossRef] [PubMed]

52. Schaller, D.; Hagenow, S.; Stark, H.; Wolber, G. Ligand-guided homology modeling drives identification of novel histamine H3 receptor ligands. PLoS ONE 2019, 14, e0218820. [CrossRef]

53. Istyastono, E.P.; Kooistra, A.J.; Vischer, H.F.; Kuijer, M.; Roumen, L.; Nijmeijer, S.; Smits, R.A.; de Esch, I.J.P.; Leurs, R.; de Graaf, C. Structure-based virtual screening for fragment-like ligands of the G protein-coupled histamine H4 receptor. MedChemComm 2015, 6, 1003-1017. [CrossRef] 
54. Herrera-Zuniga, L.D.; Moreno-Vargas, L.M.; Ballaud, L.; Correa-Basurto, J.; Prada-Gracia, D.; Pastre, D.; Curmi, P.A.; Arrang, J.M.; Maroun, R.C. A complex view of GPCR signaling: Multidimensional analysis of extended molecular dynamics simulations reveals the complexity of signal transduction by the histamine H3 membrane receptor. bioRxiv 2019. [CrossRef]

55. Sader, S.; Cai, J.; Muller, A.C.G.; Wu, C. Can human allergy drug fexofenadine, an antagonist of histamine (H1) receptor, be used to treat dog and cat? Homology modeling, docking and molecular dynamic Simulation of three H1 receptors in complex with fexofenadine. J. Mol. Graph. Model. 2017, 75, 106-116. [CrossRef]

56. Riza, Y.M.; Parves, M.R.; Tithi, F.A.; Alam, S. Quantum chemical calculation and binding modes of H1R; a combined study of molecular docking and DFT for suggesting therapeutically potent H1R antagonist. In Silico Pharmacol. 2019, 7, 1. [CrossRef] [PubMed]

57. Darras, F.H.; Pockes, S.; Huang, G.; Wehle, S.; Strasser, A.; Wittmann, H.J.; Nimczick, M.; Sotriffer, C.A.; Decker, M. Synthesis, biological evaluation, and computational studies of Tri- and tetracyclic nitrogen-bridgehead compounds as potent dual-acting AChE inhibitors and hH3 receptor antagonists. ACS Chem. Neurosci. 2014, 5, 225-242. [CrossRef] [PubMed]

58. Wittmann, H.J.; Seifert, R.; Strasser, A. Mathematical analysis of the sodium sensitivity of the human histamine H3 receptor. In Silico Pharmacol. 2014, 2, 1. [CrossRef] [PubMed]

59. Al-Jomaily, M.; Arafat, T.; Al-Kaissi, E.; Ghattas, M.; Muhi-Eldeen, Z. Synthesis of amino acetylenic benzophenone derivatives as H3-antagonists. Int. J. Pharm. Pharm. Sci. 2015, 7, 174-179.

60. Hauwert, N.J.; Mocking, T.A.M.; Da Costa Pereira, D.; Kooistra, A.J.; Wijnen, L.M.; Vreeker, G.C.M.; Verweij, E.W.E.; De Boer, A.H.; Smit, M.J.; De Graaf, C.; et al. Synthesis and Characterization of a Bidirectional Photoswitchable Antagonist Toolbox for Real-Time GPCR Photopharmacology. J. Am. Chem. Soc. 2018, 140, 4232-4243. [CrossRef]

61. Szczepanska, K.; Karcz, T.; Siwek, A.; Kuder, K.J.; Latacz, G.; Bednarski, M.; Szafarz, M.; Hagenow, S.; Lubelska, A.; Olejarz-Maciej, A.; et al. Structural modifications and in vitro pharmacological evaluation of 4-pyridyl-piperazine derivatives as an active and selective histamine H3 receptor ligands. Bioorg. Chem. 2019, 91, 103071. [CrossRef]

62. Kumar, A.; Pasam, V.R.; Thakur, R.K.; Singh, M.; Singh, K.; Shukla, M.; Yadav, A.; Dogra, S.; Sona, C.; Umrao, D.; et al. Novel Tetrahydroquinazolinamines as Selective Histamine 3 Receptor Antagonists for the Treatment of Obesity. J. Med. Chem. 2019, 62, 4638-4655. [CrossRef]

63. Geyer, R.; Nordemann, U.; Strasser, A.; Wittmann, H.-J.; Buschauer, A. Conformational restriction and enantioseparation increase potency and selectivity of cyanoguanidine-type histamine H4 receptor agonists. J. Med. Chem. 2016, 59, 3452-3470. [CrossRef] [PubMed]

64. Yang, Y.; Li, Y.; Pan, Y.; Wang, J.; Lin, F.; Wang, C.; Zhang, S.; Yang, L. Computational Analysis of Structure-Based Interactions for Novel H(1)-Antihistamines. Int. J. Mol. Sci. 2016, 17, 129. [CrossRef] [PubMed]

65. Siddalingamurthy, E.; Mahadevan, K.M.; Jagadeesh, N.M.; Kumara, M.N. Synthesis of Indolecarboxamides and Their Docking Studies with H1, 5HT and CCR2 Antagonist Receptors. Am. J. Pharm. Health Res. 2014, 2, 245-258.

66. Saxena, M.; Bhunia, S.S.; Saxena, A.K. Molecular modelling studies on 2-substituted octahydropyrazinopyridoindoles for histamine H2 receptor antagonism. SAR QSAR Environ. Res. 2015, 26, 739-755. [CrossRef] [PubMed]

67. Szczepanska, K.; Karcz, T.; Mogilski, S.; Siwek, A.; Kuder, K.J.; Latacz, G.; Kubacka, M.; Hagenow, S.; Lubelska, A.; Olejarz, A.; et al. Synthesis and biological activity of novel tert-butyl and tert-pentylphenoxyalkyl piperazine derivatives as histamine H3R ligands. Eur. J. Med. Chem. 2018, 152, 223-234. [CrossRef]

68. Jonczyk, J.; Lodarski, K.; Staszewski, M.; Godyń, J.; Zaręba, P.; Soukup, O.; Janockova, J.; Korabecny, J.; Sałat, K.; MalikowskaRacia, N.; et al. Search for multifunctional agents against Alzheimer's disease among non-imidazole histamine H3 receptor ligands. In vitro and in vivo pharmacological evaluation and computational studies of piperazine derivatives. Bioorg. Chem. 2019, 90, 103084. [CrossRef]

69. Siddalingamurthy, E.; Mahadevan, K.M.; Jagadeesh, N.M.; Kumara, M.N. Synthesis and docking study of 3-(N-Alkyl/Aryl piperidyl) indoles with serotonin-5HT, H1 and CCR2 antagonist receptors. Int. J. Pharm. Pharm. Sci. 2014, 6, 475-482.

70. Elbayaa, R.Y. Computer-aided Design, Synthesis, and Biological Evaluation of 5-Substituted Aminomethylenepyrimidine-2, 4, 6-Triones as H1 Antihistaminic Agents (Part2). Med. Chem. 2014, 10, 66-73. [CrossRef]

71. Hariono, M.; Wahab, H.A. In Silico study of $\mathrm{N}^{1}$-alkyltheobromine as histamine-H1 receptor antagonist. Int. J. Life Sci. Biotech. Pharma Res. 2015, 4, 108.

72. Kuhne, S.; Kooistra, A.J.; Bosma, R.; Bortolato, A.; Wijtmans, M.; Vischer, H.F.; Mason, J.S.; de Graaf, C.; de Esch, I.J.; Leurs, R. Identification of Ligand Binding Hot Spots of the Histamine H1 Receptor following Structure-Based Fragment Optimization. J. Med. Chem. 2016, 59, 9047-9061. [CrossRef]

73. Sureshkumar, K.; Maheshwaran, V.; Dharma Rao, T.; Themmila, K.; Ponnuswamy, M.N.; Kadhirvel, S.; Dhandayutham, S. Synthesis, characterization, crystal structure, in-vitro anti-inflammatory and molecular docking studies of 5-mercapto-1substituted tetrazole incorporated quinoline derivative. J. Mol. Struct. 2017, 1146, 314-323. [CrossRef]

74. Stoddart, L.A.; Vernall, A.J.; Bouzo-Lorenzo, M.; Bosma, R.; Kooistra, A.J.; de Graaf, C.; Vischer, H.F.; Leurs, R.; Briddon, S.J.; Kellam, B.; et al. Development of novel fluorescent histamine H1-receptor antagonists to study ligand-binding kinetics in living cells. Sci. Rep. 2018, 8, 1572. [CrossRef]

75. Soldner, C.A.; Horn, A.H.C.; Sticht, H. Binding of histamine to the H1 receptor-A molecular dynamics study. J. Mol. Model. 2018, 24, 346. [CrossRef] [PubMed] 
76. Da Silva Hage-Melim, L.I.; Poiani, J.G.C.; de Paula da Silva, C.H.T.; Boylan, F. In silico study of the mechanism of action, pharmacokinetic and toxicological properties of some N-methylanthranilates and their analogs. Food Chem. Toxicol. 2019, 131, 110556. [CrossRef]

77. Pockes, S.; Wifling, D.; Keller, M.; Buschauer, A.; Elz, S. Highly Potent, Stable, and Selective Dimeric Hetarylpropylguanidine-Type Histamine H2 Receptor Agonists. ACS Omega 2018, 3, 2865-2882. [CrossRef] [PubMed]

78. Bautista-Aguilera, O.M.; Hagenow, S.; Palomino-Antolin, A.; Farre-Alins, V.; Ismaili, L.; Joffrin, P.L.; Jimeno, M.L.; Soukup, O.; Janockova, J.; Kalinowsky, L.; et al. Multitarget-Directed Ligands Combining Cholinesterase and Monoamine Oxidase Inhibition with Histamine H3 R Antagonism for Neurodegenerative Diseases. Angew. Chem. Int. Ed. Engl. 2017, 56, 12765-12769. [CrossRef]

79. Wen, G.; Liu, Q.; Hu, H.; Wang, D.; Wu, S. Design, synthesis, biological evaluation, and molecular docking of novel flavones as H3R inhibitors. Chem. Biol. Drug Des. 2017, 90, 580-589. [CrossRef]

80. Jonczyk, J.; Malawska, B.; Bajda, M. Hybrid approach to structure modeling of the histamine H3 receptor: Multi-level assessment as a tool for model verification. PLoS ONE 2017, 12, e0186108. [CrossRef]

81. Wagner, G.; Mocking, T.A.M.; Arimont, M.; Provensi, G.; Rani, B.; Silva-Marques, B.; Latacz, G.; Da Costa Pereira, D.; Karatzidou, C.; Vischer, H.F.; et al. 4-(3-Aminoazetidin-1-yl)pyrimidin-2-amines as High-Affinity Non-imidazole Histamine H3 Receptor Agonists with in Vivo Central Nervous System Activity. J. Med. Chem. 2019, 62, 10848-10866. [CrossRef] [PubMed]

82. Wifling, D.; Löffel, K.; Nordemann, U.; Strasser, A.; Bernhardt, G.; Dove, S.; Seifert, R.; Buschauer, A. Molecular determinants for the high constitutive activity of the human histamine $\mathrm{H} 4$ receptor: Functional studies on orthologues and mutants. Br. $J$. Pharmacol. 2015, 172, 785-798. [CrossRef] [PubMed]

83. Shobana, S. Virtual Screening, Pharmacophore Modeling, and Quantitative Structure Activity Relationship Studies on Histamine 4 Receptor. Asian J. Pharm. Clin. Res. 2017, 10, 150-154. [CrossRef]

84. Jakubik, J.; El-Fakahany, E.E.; Dolezal, V. Towards predictive docking at aminergic G-protein coupled receptors. J. Mol. Model. 2015, 21, 284. [CrossRef]

85. Krzan, M.; Vianello, R.; Marsavelski, A.; Repic, M.; Zaksek, M.; Kotnik, K.; Fijan, E.; Mavri, J. The Quantum Nature of DrugReceptor Interactions: Deuteration Changes Binding Affinities for Histamine Receptor Ligands. PLoS ONE 2016, 11, e0154002. [CrossRef] [PubMed]

86. Correa, M.F.; Balico-Silva, A.L.; Kiss, D.J.; Fernandes, G.A.B.; Maraschin, J.C.; Parreiras, E.S.L.T.; Varela, M.T.; Simoes, S.C.; Bouvier, M.; Keseru, G.M.; et al. Novel potent (dihydro)benzofuranyl piperazines as human histamine receptor ligands—Functional characterization and modeling studies on H3 and H4 receptors. Bioorg Med Chem 2021, 30, 115924. [CrossRef]

87. Shankaran, K.S.; Ganai, S.A.; Arun, K.P.; Brindha, P.; Mahadevan, V. In silico and In vitro evaluation of the anti-inflammatory potential of Centratherum punctatum Cass-A. J. Biomol. Struct. Dyn. 2017, 35, 765-780. [CrossRef] [PubMed]

88. Kuder, K.J.; Lazewska, D.; Kaleta, M.; Latacz, G.; Kottke, T.; Olejarz, A.; Karcz, T.; Fruzinski, A.; Szczepanska, K.; KarolakWojciechowska, J.; et al. Synthesis and biological activity of novel tert-amylphenoxyalkyl (homo)piperidine derivatives as histamine H3R ligands. Bioorg. Med. Chem. 2017, 25, 2701-2712. [CrossRef] [PubMed]

89. Szczepanska, K.; Karcz, T.; Kotanska, M.; Siwek, A.; Kuder, K.J.; Latacz, G.; Mogilski, S.; Hagenow, S.; Lubelska, A.; Sobolewski, M.; et al. Optimization and preclinical evaluation of novel histamine H3 receptor ligands: Acetyl and propionyl phenoxyalkyl piperazine derivatives. Bioorg. Med. Chem. 2018, 26, 6056-6066. [CrossRef]

90. Xin, J.; Hu, M.; Liu, Q.; Zhang, T.T.; Wang, D.M.; Wu, S. Design, synthesis, and biological evaluation of novel iso-flavones derivatives as H3R antagonists. J. Enzyme Inhib. Med. Chem. 2018, 33, 1545-1553. [CrossRef]

91. Hamzeh-Mivehroud, M.; Khoshravan-Azar, Z.; Dastmalchi, S. QSAR and Molecular Docking Studies on Non-Imidazole-Based Histamine H3 Receptor Antagonists. Pharm. Sci. 2020, 26, 165-174. [CrossRef]

92. Kaminska, K.; Ziemba, J.; Ner, J.; Schwed, J.S.; Lazewska, D.; Wiecek, M.; Karcz, T.; Olejarz, A.; Latacz, G.; Kuder, K.; et al. (2-Arylethenyl)-1,3,5-triazin-2-amines as a novel histamine H4 receptor ligands. Eur. J. Med. Chem. 2015, 103, 238-251. [CrossRef]

93. Correa, M.F.; Dos Santos Fernandes, J.P. QSAR Modeling of Histamine H3R Antagonists/inverse Agonists as Future Drugs for Neurodegenerative Diseases. Curr. Neuropharmacol. 2018, 16, 749-757. [CrossRef]

94. Lazewska, D.; Jonczyk, J.; Bajda, M.; Szalaj, N.; Wieckowska, A.; Panek, D.; Moore, C.; Kuder, K.; Malawska, B.; Kiec-Kononowicz, K. Cholinesterase inhibitory activity of chlorophenoxy derivatives-Histamine H3 receptor ligands. Bioorg. Med. Chem. Lett. 2016, 26, 4140-4145. [CrossRef] [PubMed]

95. Kuder, K.; Lazewska, D.; Latacz, G.; Schwed, J.S.; Karcz, T.; Stark, H.; Karolak-Wojciechowska, J.; Kiec-Kononowicz, K. Chlorophenoxy aminoalkyl derivatives as histamine H(3)R ligands and antiseizure agents. Bioorg. Med. Chem. 2016, 24 , 53-72. [CrossRef] [PubMed]

96. Wifling, D.; Bernhardt, G.; Dove, S.; Buschauer, A. The Extracellular Loop 2 (ECL2) of the Human Histamine H4 Receptor Substantially Contributes to Ligand Binding and Constitutive Activity. PLoS ONE 2015, 10, e0117185. [CrossRef]

97. Karthic, V.M.; Poongodi, B.; Shanmugapriya, P.; Sivaraman, D. In-silico molecular docking analysis of potential phytotherapeutics from the medicinal herb Corallocarpus Epigaeus for treating urticaria. Int. J. Trans. Res. Ind. Med. 2019, 1, 5-12.

98. Bosma, R.; Wang, Z.; Kooistra, A.J.; Bushby, N.; Kuhne, S.; van den Bor, J.; Waring, M.J.; de Graaf, C.; de Esch, I.J.; Vischer, H.F.; et al. Route to Prolonged Residence Time at the Histamine H1 Receptor: Growing from Desloratadine to Rupatadine. J. Med. Chem. 2019, 62, 6630-6644. [CrossRef]

99. Soldner, C.A.; Horn, A.H.C.; Sticht, H. A Metadynamics-Based Protocol for the Determination of GPCR-Ligand Binding Modes. Int. J. Mol. Sci. 2019, 20, 1970. [CrossRef] [PubMed] 
100. Hou, Y.; Che, D.; Wei, D.; Wang, C.; Xie, Y.; Zhang, K.; Cao, J.; Fu, J.; Zhou, N.; He, H. Phenothiazine antipsychotics exhibit dual properties in pseudo-allergic reactions: Activating MRGPRX2 and inhibiting the H1 receptor. Mol. Immunol. 2019, 111, 118-127. [CrossRef] [PubMed]

101. Li, P.; Snyder, G.L.; Vanover, K.E. Dopamine Targeting Drugs for the Treatment of Schizophrenia: Past, Present and Future. Curr. Top. Med. Chem. 2016, 16, 3385-3403. [CrossRef] [PubMed]

102. Stepnicki, P.; Kondej, M.; Kaczor, A.A. Current Concepts and Treatments of Schizophrenia. Molecules 2018, 23, 2087. [CrossRef] [PubMed]

103. Proschak, E.; Stark, H.; Merk, D. Polypharmacology by Design: A Medicinal Chemist's Perspective on Multitargeting Compounds. J. Med. Chem. 2019, 62, 420-444. [CrossRef] [PubMed]

104. Bolognesi, M.L. Harnessing Polypharmacology with Medicinal Chemistry. ACS Med. Chem. Lett. 2019, 10, 273-275. [CrossRef]

105. Mota, F.V.B.; de Araujo Neta, M.S.; de Souza Franco, E.; Bastos, I.; da Araujo, L.C.C.; da Silva, S.C.; de Oliveira, T.B.; Souza, E.K.; de Almeida, V.M.; Ximenes, R.M.; et al. Evaluation of anti-inflammatory activity and molecular docking study of new aza-bicyclic isoxazoline acylhydrazone derivatives. MedChem Comm 2019, 10, 1916-1925. [CrossRef] [PubMed]

106. Sumathi, M.; Shanmugapriya, C.; Meenakumari, R. Evaluation of anti-inflammatory, anti-allergic and immune modulatory potential of siddha formulation Oma Legium by computational docking analysis. Eur. J. Biomed. Pharm. Sci. 2017, 4, 549-556.

107. Daddam, J.R.; Sreenivasulu, B.; Peddanna, K.; Umamahesh, K. Designing, docking and molecular dynamics simulation studies of novel cloperastine analogues as anti-allergic agents: Homology modeling and active site prediction for the human histamine H1 receptor. RSC Adv. 2020, 10, 4745-4754. [CrossRef]

108. Gurjar, V.K.; Pal, D. Design, in silico studies, and synthesis of new 1,8-naphthyridine-3-carboxylic acid analogues and evaluation of their H1R antagonism effects. RSC Adv. 2020, 10, 13907-13921. [CrossRef]

109. Mobarec, J.C.; Filizola, M. Advances in the Development and Application of Computational Methodologies for Structural Modeling of G-Protein Coupled Receptors. Expert. Opin. Drug Discov. 2008, 3, 343-355. [CrossRef] [PubMed]

110. Chaudhari, R.; Heim, A.J.; Li, Z. Improving homology modeling of G-protein coupled receptors through multiple-template derived conserved inter-residue interactions. J. Comput. Aided Mol. Des. 2015, 29, 413-420. [CrossRef]

111. Costanzi, S.; Wang, K. The GPCR crystallography boom: Providing an invaluable source of structural information and expanding the scope of homology modeling. Adv. Exp. Med. Biol. 2014, 796, 3-13. [CrossRef]

112. Yang, J.; Yan, R.; Roy, A.; Xu, D.; Poisson, J.; Zhang, Y. The I-TASSER Suite: Protein structure and function prediction. Nat. Methods 2015, 12, 7-8. [CrossRef]

113. Webb, B.; Sali, A. Protein Structure Modeling with MODELLER. Methods Mol. Biol. 2017, 1654, 39-54. [CrossRef]

114. Biasini, M.; Bienert, S.; Waterhouse, A.; Arnold, K.; Studer, G.; Schmidt, T.; Kiefer, F.; Cassarino, T.G.; Bertoni, M.; Bordoli, L.; et al. SWISS-MODEL: Modelling protein tertiary and quaternary structure using evolutionary information. Nucleic Acids Res. 2014, 42, 252-258. [CrossRef] [PubMed]

115. Kelley, L.A.; Mezulis, S.; Yates, C.M.; Wass, M.N.; Sternberg, M.J. The Phyre2 web portal for protein modeling, prediction and analysis. Nat. Protoc. 2015, 10, 845-858. [CrossRef]

116. Colovos, C.; Yeates, T.O. Verification of protein structures: Patterns of nonbonded atomic interactions. Protein Sci. 1993, 2, 1511-1519. [CrossRef]

117. Laskowski, R.A.; MacArthur, M.W.; Moss, D.S.; Thornton, J.M. PROCHECK: A program to check the stereochemical quality of protein structures. J. Appl. Cryst. 1993, 26, 283-291. [CrossRef]

118. Chaudhary, A.; Yadav, B.S.; Singh, S.; Maurya, P.K.; Mishra, A.; Srivastva, S.; Varadwaj, P.K.; Singh, N.K.; Mani, A. Docking-based Screening of Ficus religiosa Phytochemicals as Inhibitors of Human Histamine H2 Receptor. Pharmacogn. Mag. 2017, 13, S706-S714. [CrossRef]

119. Singh, V.; Gohil, N.; Ramirez-Garcia, R. New insight into the control of peptic ulcer by targeting the histamine H2 receptor. J. Cell. Biochem. 2018, 119, 2003-2011. [CrossRef]

120. Boddupally, S.; Gunda, S.K.; Naga Harini, P.; Shaik, M. In silico predictive studies of histamine H2 receptor protein binding using homology modelling and molecular docking. Res. J. Life Sci. Bioinf. Pharm. Chem. Sci. 2019, 5, 500-514. [CrossRef]

121. Lazewska, D.; Bajda, M.; Kaleta, M.; Zareba, P.; Doroz-Plonka, A.; Siwek, A.; Alachkar, A.; Mogilski, S.; Saad, A.; Kuder, K.; et al. Rational design of new multitarget histamine $\mathrm{H} 3$ receptor ligands as potential candidates for treatment of Alzheimer's disease. Eur. J. Med. Chem. 2020, 207, 112743. [CrossRef]

122. Bajda, M.; Lazewska, D.; Godyn, J.; Zareba, P.; Kuder, K.; Hagenow, S.; Latka, K.; Stawarska, E.; Stark, H.; Kiec-Kononowicz, K.; et al. Search for new multi-target compounds against Alzheimer's disease among histamine H3 receptor ligands. Eur. J. Med. Chem. 2020, 185, 111785. [CrossRef]

123. Yuan, S.; Filipek, S.; Palczewski, K.; Vogel, H. Activation of G-protein-coupled receptors correlates with the formation of a continuous internal water pathway. Nat. Commun. 2014, 5, 4733. [CrossRef]

124. Yuan, S.; Hu, Z.; Filipek, S.; Vogel, H. W246(6.48) opens a gate for a continuous intrinsic water pathway during activation of the adenosine A2A receptor. Angew. Chem. Int. Ed. 2015, 54, 556-559. [CrossRef]

125. Kim, S.K.; Fristrup, P.; Abrol, R.; Goddard, W.A., 3rd. Structure-based prediction of subtype selectivity of histamine H3 receptor selective antagonists in clinical trials. J. Chem. Inf. Model. 2011, 51, 3262-3274. [CrossRef]

126. Lavecchia, A.; Di Giovanni, C. Virtual screening strategies in drug discovery: A critical review. Curr. Med. Chem. 2013, 20, 2839-2860. [CrossRef] [PubMed] 
127. Ghamari, N.; Dastmalchi, S.; Zarei, O.; Arias-Montaño, J.A.; Reiner, D.; Ustun-Alkan, F. In silico and in vitro studies of two non-imidazole multiple targeting agents at histamine $\mathrm{H} 3$ receptors and cholinesterase enzymes. Chem. Biol. Drug Des. 2020, 95, 279-290. [CrossRef] [PubMed]

128. Koes, D.R.; Camacho, C.J. ZINCPharmer: Pharmacophore search of the ZINC database. Nucleic Acids Res. 2012, 40, W409-W414. [CrossRef]

129. Wolber, G.; Langer, T. LigandScout: 3-D Pharmacophores Derived from Protein-Bound Ligands and Their Use as Virtual Screening Filters. J. Chem. Inf. Model. 2005, 45, 160-169. [CrossRef]

130. Sadek, B.; Stark, H. Cherry-picked ligands at histamine receptor subtypes. Neuropharmacology 2016, 106, 56-73. [CrossRef]

131. Jayaraju, A.; Sreeramulu, J. Synthesis, insilico studies and biological evaluation of pramepexole carbamodithiolate metal complexes. J. Chem. Pharm. Res. 2016, 8, 884-890.

132. Miszta, P.; Pasznik, P.; Jakowiecki, J.; Sztyler, A.; Latek, D.; Filipek, S. GPCRM: A homology modeling web service with triple membrane-fitted quality assessment of GPCR models. Nucleic Acids Res. 2018, 46, W387-W395. [CrossRef] [PubMed]

133. Schihada, H.; Ma, X.; Zabel, U.; Vischer, H.F.; Schulte, G.; Leurs, R. Development of a Conformational Histamine H3 Receptor Biosensor for the Synchronous Screening of Agonists and Inverse Agonists. ACS Sens. 2020, 5, 1734-1742. [CrossRef]

134. Song, M.; Yan, R.; Zhang, Y.; Guo, D.; Zhou, N.; Deng, X. Design, synthesis, and anticonvulsant effects evaluation of nonimidazole histamine H3 receptor antagonists/inverse agonists containing triazole moiety. J. Enzyme Inhib. Med. Chem. 2020, 35, 1310-1321. [CrossRef] [PubMed]

135. Lim, H.D.; de Graaf, C.; Jiang, W.; Sadek, P.; McGovern, P.M.; Istyastono, E.P.; Bakker, R.A.; de Esch, I.J.P.; Thurmond, R.L.; Leurs, R. Molecular determinants of ligand binding to H4R species variants. Mol. Pharmacol. 2010, 77, 734-743. [CrossRef]

136. Isberg, V.; de Graaf, C.; Bortolato, A.; Cherezov, V.; Katritch, V.; Marshall, F.H.; Mordalski, S.; Pin, J.P.; Stevens, R.C.; Vriend, G.; et al. Generic GPCR residue numbers-Aligning topology maps while minding the gaps. Trends Pharmacol. Sci. 2015, 36, 22-31. [CrossRef]

137. Mehta, P.; Miszta, P.; Rzodkiewicz, P.; Michalak, O.; Krzeczyński, P.; Filipek, S. Enigmatic Histamine Receptor H4 for Potential Treatment of Multiple Inflammatory, Autoimmune, and Related Diseases. Life (Basel) 2020, 10, 50. [CrossRef]

138. Woolley, M.J.; Conner, A.C. Understanding the common themes and diverse roles of the second extracellular loop (ECL2) of the GPCR super-family. Mol. Cell. Endocrinol. 2017, 449, 3-11. [CrossRef] [PubMed]

139. Mogilski, S.; Kubacka, M.; Łażewska, D.; Więcek, M.; Głuch-Lutwin, M.; Tyszka-Czochara, M.; Bukowska-Strakova, K.; Filipek, B.; Kieć-Kononowicz, K. Aryl-1,3,5-triazine ligands of histamine H4 receptor attenuate inflammatory and nociceptive response to carrageen, zymosan and lipopolysaccharide. Inflamm. Res. 2016, 66, 79-95. [CrossRef] [PubMed] 